\title{
UMTRA PROJECT ENVIRONMENT, SAFETY, and Health Plan
}

February 1995 
This report has been reproduced from the best available copy. Available in paper copy and microfiche

Number of pages in this report: 128

DOE and DOE contractors can obtain copies of this report from:

Office of Scientific and Technical Information

P.O. Box 62

Oak Ridge, TN 37831

(615) 576-8401

This report is publicly available from:

National Technical Information Service

Department of Commerce

5285 Port Royal Road

Springfield, VA 22161

(703) $487-4650$ 


\section{UMTRA PROJECT \\ ENVIRONMENT, SAFETY AND HEALTH PLAN}

SIGNATURE PAGE

Reviewed By:

Bennett Young

Date

Environment, Safety, and Health Manager

DOE UMTRA Project Office

Reviewed By:

Robert Cornish

Date

Radiation Protection Manager

DOE UMTRA Project Office

Approved By:

Frank Bosiljevac

Technical Support Group Leader

DOE UMTRA Project Office

Approved By:

Clinton Smythe

Engineering and Construction Group Leader

Date

DOE UMTRA Project Office

Approved By:

Charles Cormier

Date

Acting Project Manager

DOE UMTRA Project Office 


\section{DISCLAIMER}

Portions of this document may be illegible in electronic image products. Images are produced from the best available original document. 
February 1995

This document supersedes document number UMTRA-DOE/AL-150224.0006

\author{
Prepared for \\ U.S. Department of Energy \\ UMTRA Project Office \\ Albuquerque, New Mexico \\ Prepared by \\ Jacobs Engineering Group Inc. \\ Albuquerque, New Mexico
}

\title{
DISCLAIMER
}

\begin{abstract}
This report was prepared as an account of work sponsored by an agency of the United States Government. Neither the United States Government nor any agency thereof, nor any of their employees, makes any warranty, express or implied, or assumes any legal liability or responsibility for the accuracy, completeness, or usefulness of any information, apparatus, product, or process disclosed, or represents that its use would not infringe privately owned rights. Reference herein to any specific commercial product, process, or service by trade name, trademark, manufacturer, or otherwise does not necessarily constitute or imply its endorsement, recommendation, or favoring by the United States Government or any agency thereof. The views and opinions of authors expressed herein do not necessarily state or reflect those of the United States Government or any agency thereof.
\end{abstract}


TABLE OF CONTENTS

Section

Page

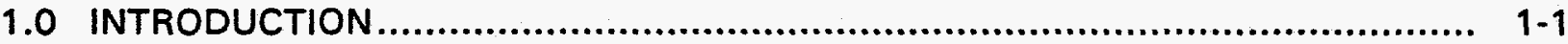

1.1 Purpose and scope........................................................................... 1-1

1.2 UMTRA Project ES\&H Policy........................................................ 1-1

1.3 UMTRA Project ES\&H goals............................................................ 1-1

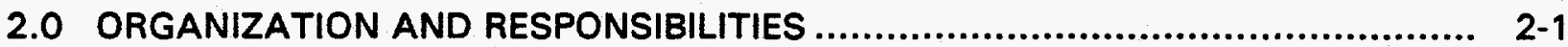

2.1 Organization and structure.......................................................... $2-1$

2.2 UMTRA Project Office responsibilities............................................. 2-1

2.3 Remedial action contractor responsibilities ...................................... $2-4$

2.4 Technical assistance contractor responsibilities.................................. 2-5

2.5 UMTRA Project ES\&H Committee............................................. 2-7

3.0 GENERAL ES\&H PROGRAM GUIDANCE............................................... $3-1$

3.1 ES\&H operating envelope ....................................................... $3-1$

3.2 Staffing ............................................................................. 3

3.3 Program plans and procedures .................................................. 3

3.4 Worker training ....................................................................... 3

3.5 Records and reporting requirements .............................................. $3-4$

3.6 Complaints ..................................................................... $3-4$

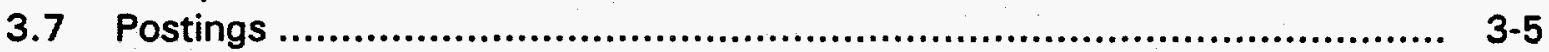

3.8 Oversight programs ............................................................... $3-5$

3.9 Stop work and restart authority............................................... $3-6$

4.0 HEALTH AND SAFETY PLAN REQUIREMENTS ......................................... $4-1$

4.1 Introduction ........................................................................ 4

4.2 Key personnel ....................................................................... 4-1

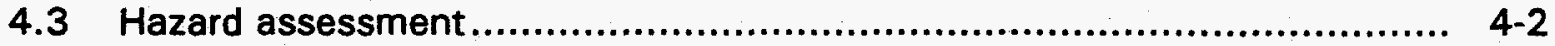

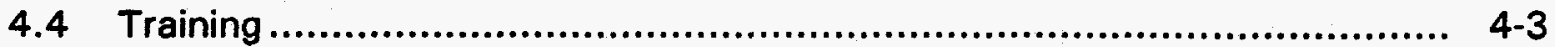

4.5 Personal protective equipment ............................................... 4-4

4.6 Medical program.................................................................. 4-5

4.6.1 Medical surveillance ...................................................... 4-5

4.6.2 First aid and response to medical emergencies ........................ 4-6

4.7 Exposure monitoring and air sampling ....................................... 4-6

4.8 Site control ........................................................................ 4-7

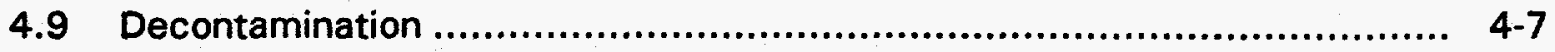

4.10 Special health and safety program elements ................................... 4-8

4.10.1 Radiation Protection Program .......................................... 4-8

4.10.2 Industrial Hygiene Program ............................................... 4-9

4.10.3 Vehicle or Transportation Safety Program .............................. 4-10

4.10.4 Construction Safety Program ............................................ 4-10

4.10.5 Fire Protection Program................................................. 4-11

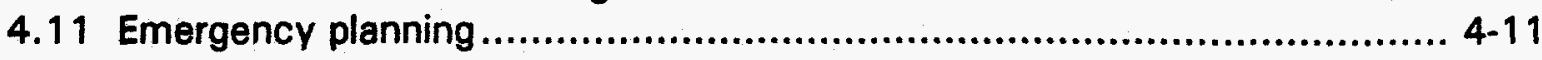


TABLE OF CONTENTS (Concluded)

Section

Page

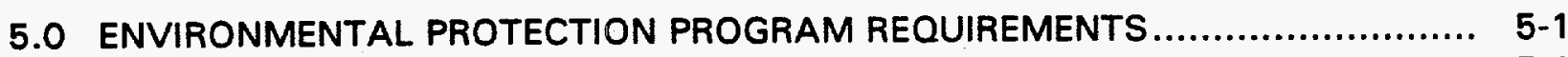

5.1 Environmental compliance .................................................... $5-1$

5.1.1 NEPA compliance ........................................................ $5-1$

5.1.2 Permit compliance ..................................................... $5-1$

5.2 Environmental monitoring ..................................................... $5-2$

5.3 Special environmental programs ............................................ $5-3$

5.3.1 Ground Water Protection Management Program...................... 5-3

5.3.2 Waste Minimization/Pollution Prevention Awareness Program....... 5-3

5.4 Annual environmental report ............................................. $5-3$

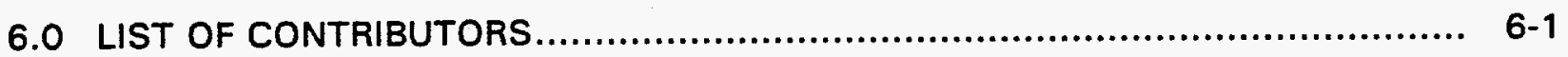

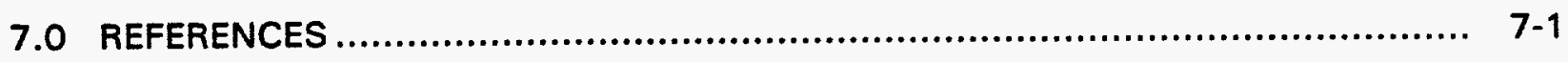

ATTACHMENT 1 REGULATIONS APPLICABLE TO THE UMTRA PROJECT

ATTACHMENT 2 UMTRA PROJECT AUDITABLE SAFETY ANALYSIS 


\section{LIST OF FIGURES}

\section{Figure}

Page

1.1 UMTRA Project Environment, Safety, and Health Policy.......................... 1-2

2.1 UMTRA Project Office Organization Chart ......................................... $2-2$ 


\section{LIST OF ACRONYMS}

Acronym

ANSI

ALARA

DOE

DOE/AL

EAP

ES\&H

ESHOE

HASP

HAZWOPER

NEPA

NFPA

NRC

OSHA

PPE

PRID

RAC

S/RID

TAC

UMTRA

\section{Definition}

American National Standards Institute

as low as reasonably achievable

U.S. Department of Energy

DOE Albuquerque Operations Office

emergency action plan

environment, safety, and health

ES\&H Operating Envelope

health and safety plan

Hazardous Waste Operations and Emergency Response

National Environmental Policy Act

National Fire Protection Association

U.S. Nuclear Regulatory Commission

Occupational Safety and Health Administration

personal protection equipment

Preliminary Requirements Identification Database

Remedial Action Contractor

Standards/Requirements Identification Database

Technical Assistance Contractor

Uranium Mill Tailings Remedial Action 


\subsection{INTRODUCTION}

\section{$1.1 \quad$ PURPOSE AND SCOPE}

The U.S. Department of Energy (DOE) Uranium Mill Tailings Remedial Action (UMTRA) Project Office has prepared this UMTRA Project Environment, Safety, and Health (ES\&H) Plan to establish the policy, implementing requirements, and guidance for the UMTRA Project. The requirements and guidance identified in this plan are designed to provide technical direction to UMTRA Project contractors to assist in the development and implementation of their ES\&H plans and programs for UMTRA Project work activities.

Specific requirements set forth in this UMTRA Project ES\&H Plan are intended to provide uniformity to the UMTRA Project's ES\&H programs for processing sites, disposal sites, and vicinity properties. In all cases, this UMTRA Project ES\&H Plan is intended to be consistent with applicable standards and regulations and to provide guidance that is generic in nature and will allow for contractors' evaluation of site- or contract-specific ES\&H conditions.

This plan specifies the basic ES\&H requirements applicable to UMTRA Project ES\&H programs and delineates responsibilities for carrying out this plan. DOE and contractor ES\&H personnel are expected to exercise professional judgment and apply a graded approach when interpreting these guidelines, based on the risk of operations.

\subsection{UMTRA PROJECT ES\&H POLICY}

The UMTRA Project Office and its contractors, under site/contract ES\&H programs, shall take all reasonable precautions in the performance of UMTRA Project work to protect the health and safety of employees and the public and to protect the environment. To this end, UMTRA Project operations shall comply with the letter and spirit of all applicable Federal, state, tribal, and local statutes, regulations and requirements, including DOE Orders. The UMTRA Project Office has stated this commitment in the UMTRA Project ES\&H Policy (Figure 1.1).

\section{$1.3 \quad$ UMTRA PROJECT ES\&H GOALS}

The UMTRA Project Office's ES\&H Policy states that the Project's overall goal is to achieve its mission while meeting or exceeding all applicable Federal, state, tribal, and local requirements. It is also a Project Office goal that UMTRA Project ES\&H programs be recognized as the standard for other DOE environmental restoration programs.

In addition, the Project Office has set the following specific goals. 


\section{UMTRA PROJECT ENVIRONMENT, SAFETY, AND HEALTH POLICY}

The DOE's Uranium Mill Tailings Remedial Action (UMTRA) Project is an environmental restoration and protection program. The UMTRA Project's congressionally mandated mission is to clean up and control residual radioactive materials from designated inactive uranium processing sites and to eliminate present and future environmental health hazards that may result from those materials. The UMTRA Project's goal is to achieve its mission in a manner that protects the public and the environment; ensures the safety and health of workers; and meets or exceeds the requirements of applicable Federal, state, tribal, and local laws, regulations, and permits, utilizing best management practices. To achieve this goal, the UMTRA Project Office has prepared and is implementing the UMTRA Project Environment, Safety, and Health Plan.

The UMTRA Project is firmly committed to implementing the most technologically advanced environmental protection practices while following proactive safety and health management policies and goals. Accordingly, the UMTRA Project Office's policy is to conduct operations in compliance with both the letter and the spirit of applicable environment, safety, and health statutes, regulations, and standards and to strive for continuous improvement and excellence rather than just compliance. The UMTRA Project is committed to sound environmental management and worker safety practices; minimizing the risks to the environment, the public, and workers; and anticipating and addressing potential problems before they pose a threat to the environment or the public. The UMTRA Project also is committed to employing best management practices to minimize the generation of contaminants, wastes, and other residual materials requiring disposal or release to the environment through source reduction, recycling, treatment, and pollution prevention awareness.

Protection of the environment, workers, and the public is of paramount importance to the DOE and the UMTRA Project. Project activities have always recognized this, and as a result, the Project experiences a level of public trust not evident in many environmental restoration endeavors. The UMTRA Project Office's policy is that its contractors shall incorporate this commitment to worker safety and environmental protection in all of their activities. The Project Office requires its contractors to conduct their operations in an environmentally sound and safe manner that keeps the risks to the environment, workers, and the public as low as reasonably achievable. The Project Office actively oversees its contractors' activities to ensure compliance with this policy.

Charles A. Cormier

Acting Project Manager

DOE UMTRA Project Office

December 1994

FIGURE 1.1

UMTRA PROJECT ENVIRONMENT, SAFETY, AND HEALTH POLICY 
- Radiological protection goals: Occupational exposures to ionizing radiation should not exceed 500 millirem/year committed effective dose equivalent and should be as low as reasonably achievable (ALARA). Personnel contamination rates should be below DOE average rates.

- Industrial hygiene goals: Occupational exposures to chemicals and physical and biological hazards should be kept at or below 50 percent of either the applicable threshold limit value or the permissible exposure limit, whichever is less. When neither limit exists, exposures should be kept at or below 50 percent of an appropriate recommended exposure limit established by the substance's material safety data sheet or other recognized source.

- Occupational safety goals: There should be no fatalities. Lost workday and recordable injury incidence rates should be below the DOE average rates for construction.

- Environmental protection goals: Environmental releases from UMTRA Project operations should be kept below permit limits and other applicable requirements. There should be no violations of environmental permits or applicable regulations. 


\subsection{ORGANIZATION AND RESPONSIBILITIES}

The nature of the UMTRA Project does not always lend itself to classical organizational structure which strictly separates line management and oversight organizations. However, lines of functional authority for ES\&H management should be independent of those for line management to ensure that UMTRA Project ES\&H oversight functions are not overridden by operational concerns.

The UMTRA Project Office has established an effective ES\&H program by dividing ES\&H responsibilities between two groups (Figure 2.1). Line management responsibilities generally address remediation activities, but also include implementation of ES\&H programs, and are handled by the Engineering and Construction Group. Oversight responsibilities address identification of ES\&H requirements and compliance with regulatory requirements and specifications and are handled by the Technical Support Group. The Project Office also receives technical assistance from the DOE Albuquerque Operations Office (DOE/AL) ES\&H staff.

The UMTRA Project Remedial Action Contractor (RAC) and Technical Assistance Contractor (TAC) are contractually required to implement the UMTRA Project ES\&H Plan by developing ES\&H programs commensurate with the radiological, industrial, and construction hazards associated with their activities. Contractor organizational descriptions are provided in ES\&H documents prepared by the RAC and the TAC to clearly indicate the lines of authority and functional responsibilities for appropriate organizational units. The UMTRA Project Technical Support Group Leader, serving as the DOE Contracting Officer Representative, approves contractors' ES\&H program implementation plans.

Specific ES\&H responsibilities of the UMTRA Project Office, the RAC, and the TAC are provided in the following sections. All UMTRA Project employees must remember that UMTRA Project ES\&H programs benefit everyone working on the Project and are not just the responsibility of line management or the ES\&H professionals. All UMTRA Project employees must take personal responsibility for incorporating good ES\&H practices in their daily activities, identifying and reporting existing or potential hazards, and recommending improvements to UMTRA Project ES\&H programs.

\section{$2.2 \quad$ UMTRA PROJECT OFFICE RESPONSIBILITIES}

The UMTRA Project Manager has overall responsibility for implementing the UMTRA Project ES\&H program and for assuring that UMTRA Project contractors develop and implement ES\&H programs that are consistent with this UMTRA Project ES\&H Plan. 


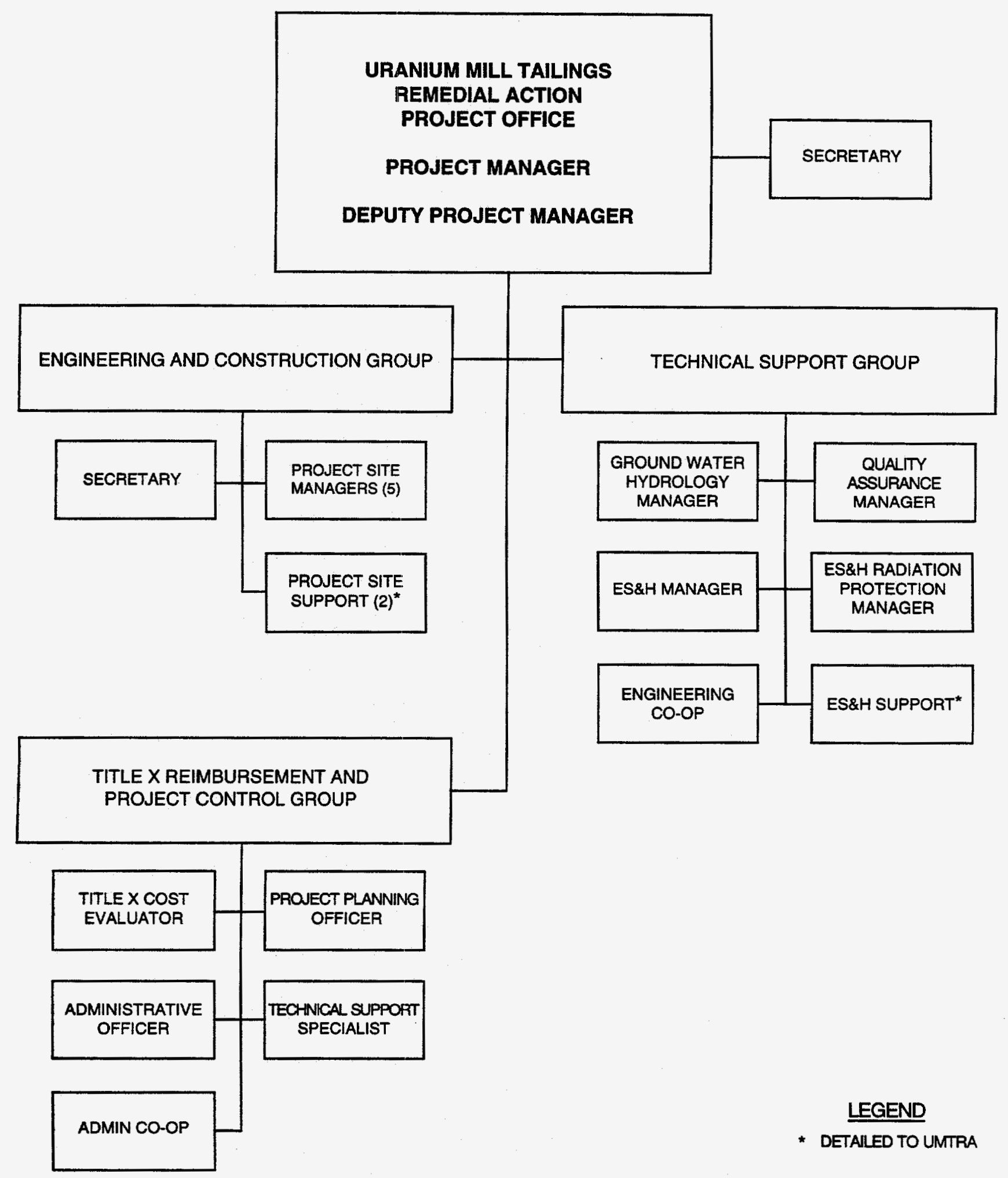

FIGURE 1.5

UMTRA PROJECT ORGANIZATION 
The Engineering and Construction Group shall have the following ES\&H line management responsibilities:

- Acting on employee ES\&H concerns in accordance with procedures outlined in this plan.

- Considering, in contract renewal or in reviews of UMTRA Project contractor performance, violations of all prescribed ES\&H standards and the timing and manner of correction.

- Assuring adequate resources are available for implementing effective ES\&H programs.

The Technical Support Group shall have the following ES\&H responsibilities:

- Issuing the UMTRA Project ES\&H Plan and the environmental protection program plans required by DOE Order 5400.1, and periodically revising these plans to reflect current guidelines and experience gained.

- Establishing the ES\&H regulatory operating envelope for the UMTRA Project.

- Establishing and maintaining the UMTRA Project Federal Employee Occupational Safety and Health Program.

- Evaluating each project to identify other local, state, tribal, or Federal agencies with ES\&H responsibility and ensuring that contractors comply with all requirements.

- Conducting periodic ES\&H audits and readiness assessments or operational readiness evaluations of contractors in accordance with applicable DOE Orders, DOE good practices, and the UMTRA Project ES\&H Plan, and issuing audit reports.

- Issuing guidance to UMTRA Project contractors and participating in the development of implementation plans and procedures for new ES\&H standards or modifications to existing standards.

- Assessing the impacts of UMTRA Project activities on the environment in accordance with the National Environmental Policy Act (42 USC \$4321 et seq.).

- Chairing the UMTRA Project ES\&H Committee, determining membership, setting agendas, assigning actions, and ensuring Committee reports are distributed to appropriate project management.

- Issuing the annual UMTRA Project environmental report required by DOE Order 5400.1. 
Both the Technical Support Group and Engineering and Construction Group, with the assistance of appropriate DOE/AL divisions, shall have the following ES\&H responsibilities:

- Identifying which contractors are to be covered by the UMTRA Project ES\&H Plan, and including the requirement for plan compliance in applicable contracts.

- Encouraging contractors to strive for continuous improvement in the conduct of their ES\&H programs.

- Reviewing and evaluating requests for variances from this plan submitted by contractor organizations.

\subsection{REMEDIAL ACTION CONTRACTOR RESPONSIBILITIES}

The UMTRA Project RAC must respond to the following ES\&H policy mandates:

- Comply with this UMTRA Project ES\&H Plan and other applicable plans and regulatory requirements as directed by the DOE Contracting Officer.

- Develop implementation procedures for the requirements set forth in this plan and any site-specific ES\&H issues identified prior to and during remedial action.

- Develop specific programs to address health and safety requirements including, but not limited to, industrial hygiene, hazard awareness and communication, exposure monitoring, fire protection, construction safety, transportation safety, and radiation protection.

- Develop specific programs to address environmental protection requirements including, but not limited to, effluent monitoring, environmental surveillance, surface water and ground water protection, waste management and minimization, and pollution prevention awareness.

- Identify subcontractors that are covered by the intent of this plan, pass on to subcontractors applicable portions of the plan, and include the requirement for compliance with the plan in applicable subcontracts.

- Ensure that all of its subcontractors comply with the UMTRA Project ES\&H Plan and other applicable requirements, as specified in the contract.

- Ensure that adequate engineering controls are implemented, or appropriate personal protective equipment is provided to and used by workers at UMTRA Project sites under their control, to meet the ES\&H goals stated in this plan. 
- Conduct internal ES\&H audits of RAC UMTRA Project activities, including those of RAC subcontractors, prepare audit reports, and verify corrective actions taken.

- Conduct readiness assessments or operational readiness reviews of RAC UMTRA Project activities.

- Implement corrective actions for any findings resulting from ES\&H audits.

- Submit requests for variance from the requirements of this plan, including justification, to the UMTRA Project Manager.

- Assist in revision of the UMTRA Project ES\&H Plan, environmental protection implementation plan, and environmental monitoring plan. Support preparation of the annual UMTRA Project environmental report.

- Ensure that specific information is recorded and reported as required by DOE Orders 5484.1 and 5000.3B.

- Assist with the development and maintenance of the ES\&H Operating Envelope (ESHOE) databases.

- Serve on the UMTRA Project ES\&H Committee.

\subsection{TECHNICAL ASSISTANCE CONTRACTOR RESPONSIBILITIES}

The UMTRA Project TAC shall respond to the following ES\&H policy mandates:

- Comply with the UMTRA Project ES\&H Plan and other applicable plans and regulatory requirements as directed by the DOE Contracting Officer.

- Develop specific programs to address health and safety requirements including, but not limited to, industrial hygiene, hazard communication, office safety, drilling safety, and radiation protection.

- Develop specific programs to address environmental protection requirements including, but not limited to, site characterization, groundwater protection and monitoring, long-term surveillance, waste management and minimization, and pollution prevention awareness.

- Maintain and revise the UMTRA Project ES\&H Plan, as necessary.

- Maintain and revise the UMTRA Project Federal Employee Occupational Safety and Health Program Plan, and assist the Project Office with implementation of the program. 
- Identify subcontractors that are covered by the intent of this plan, pass on to subcontractors applicable portions of the plan, and include the requirement for compliance with the plan in applicable subcontracts.

- Ensure that adequate engineering controls are implemented, or appropriate personal protective equipment is provided to and used by workers, at UMTRA Project sites under their control to meet the ES\&H goals stated in this plan.

- Assist the UMTRA Project Office by conducting ES\&H audits of RAC programs. Compare implementation of RAC programs to requirements in this document and to site-specific procedures and plans developed by the RAC. Prepare audit reports based on the findings of ES\&H audits, and verify any corrective actions taken by the RAC.

- $\quad$ Assist the UMTRA Project Office conduct readiness assessments or operational readiness evaluations of RAC operations.

- Conduct internal ES\&H audits of TAC UMTRA Project activities, including those of subcontractors, prepare audit reports, and verify corrective actions taken.

- Implement corrective actions for findings resulting from ES\&H audits.

- Submit requests for variance from the requirements of this plan, including justification, to the UMTRA Project Manager.

- Prepare NEPA documentation for UMTRA Project activities in accordance with DOE NEPA implementing procedures in 10 CFR Part 1021.

- Ensure that required information is recorded and reported for the TAC and its subcontractors, as required by DOE Orders 5484.1 and 5000.3B. Assist the Project Office in administering the UMTRA Project Occurrence Reporting and Processing System program.

- Maintain and revise UMTRA Project environmental protection program documentation required by DOE Order 5400.1 including the environmental protection implementation plan, environmental monitoring plan, ground water protection management program plan, ground water monitoring program plan, and waste minimization and pollution prevention awareness program plan.

- Serve on the UMTRA Project ES\&H Committee, and assist the UMTRA Project Office with the administration of the Committee.

- Contribute to and coordinate the production of the annual UMTRA Project environmental report. 
- Develop and maintain the UMTRA Project ES\&H regulatory implementation plan and operating procedures. Maintain the ESHOE system and databases in accordance with the plan and procedures.

\subsection{UMTRA PROJECT ES\&H COMMITTEE}

The UMTRA Project Office has established the UMTRA Project ES\&H Committee, whose membership includes ES\&H staff from the DOE, TAC, and RAC, to coordinate UMTRA Project ES\&H programs. The UMTRA Project Office ES\&H Manager chairs the committee. The UMTRA Project ES\&H Committee shall have certain tasks:

- Evaluate new and revised ES\&H regulations and requirements.

- Assist UMTRA Project participants with the implementation of identified ES\&H requirements.

- Validate ES\&H audit findings and identify programmatic issues.

- Track ES\&H action items and programmatic audit findings.

- Identify new and revised requirements for inclusion in the ESHOE databases and ensure TAC maintenance of the ESHOE system and databases.

- $\quad$ Address ALARA issues and function as the UMTRA Project ALARA Committee in accordance with the Radiological Control Manual (DOE, 1994a).

- Hold regular meetings to discuss ES\&H issues affecting the UMTRA Project. 


\subsection{GENERAL ES\&H PROGRAM GUIDANCE}

All UMTRA Project ES\&H programs shall be developed and implemented in a manner that complies with the UMTRA Project ES\&H Policy and will aim to achieve the UMTRA Project's ES\&H goals.

Effective, high-quality ES\&H programs must contain the following:

- Clearly defined chains of command and assignment of responsibilities.

- Accountability for program performance.

- Well-defined program goals and expectations.

- Well-defined task and operational hazards and risks.

- Comprehensive hazard prevention and control procedures.

- Recordkeeping requirements for tracking program progress.

3.1

ES\&H OPERATING ENVELOPE

UMTRA Project activities are subject to most Federal statutes and Executive Orders governing ES\&H issues including, but not limited to, the following:

Atomic Energy Act (42 USC $\$ 2011$ et seq.).

Clean Water Act (33 USC \$1251 et seq.).

Clean Air Act (42 USC $\$ 7401$ et seq.).

Emergency Planning and Community Right-To-Know Act (42 USC $\$ 11001$ et seq.).

Endangered Species Act (15 USC $\$ 1531$ et seq.).

Executive Order 11988.

Executive Order 11990.

Federal Mine Safety and Health Act (30 USC $\$ 957$ et seq.).

Hazardous Materials Transportation Act (49 USC $\$ 1801$ et seq.).

National Environmental Policy Act (42 USC $\$ 4321$ et seq.).

National Historic Preservation Act (16 USC $\$ 470$ et seq.).

Occupational Safety and Health Act (29 USC $\$ 651$ et seg.). 
Resource Conservation and Recovery Act (42 USC $\$ 6901$ et seq.).

Uranium Mill Tailings Radiation Control Act (42 USC $\$ 7922$ et seq.).

These statutes and orders are primarily implemented through regulations found in Titles $10,29,40$, and 49 of the Code of Federal Regulations (CFR), associated state regulations, and supporting codes and standards, including DOE Orders and standards, and Occupational Safety and Health Administration (OSHA), Environmental Protection Agency (EPA), Nuclear Regulatory Commission (NRC). American National Standards institute (ANSI), and National Fire Protection Association (NFPA) documents.

The specific regulatory requirements applicable to individual contractors and site operations will vary depending on specific equipment used, activities performed, work location, and DOE Contracting Officer direction. The UMTRA Project ES\&H Committee has reviewed over 1600 regulatory documents and determined that the regulations listed in Attachment 1 effectively control most UMTRA Project activities. Attachment 1 only lists state regulations for the state of Colorado since the majority of surface remedial action activities were in Colorado when this review was performed. The applicability justifications generated during this review are recorded in the Preliminary Requirements Identification Database (PRID) element of the ESHOE system.

UMTRA Project contractors shall review the listed regulations and identify the applicable requirements for each site or contract activity to ensure that all regulatory issues are addressed. Other pertinent regulations also need to be reviewed to determine their applicability. The results of these reviews shall be reported to the Project Office to be recorded in the PRID.

The Standards/Requirernents Identification Database (S/RID) element of the ESHOE system should be used to derive the regulatory operating envelope for each new UMTRA Project site. The S/RID contains the mandatory statements from regulations applicable to UMTRA Project operations. The S/RID will be updated to reflect regulatory document changes and the results of applicability analyses.

When the contractors determine the operating envelope for an UMTRA Project site or specific operation, the actual equipment and processes to be used should be considered in their review process to ensure that all appropriate ES\&H criteria have been addressed.

\subsection{STAFFING}

The contractor(s) having ES\&H responsibilities at a site or associated vicinity properties shall have qualified individuals with properly trained staff responsible for health and safety of the workers and public, and protection of the environment. ES\&H staff qualifications and training should be commensurate 
with the potential health and safety hazards, environmental threats, and job size.

\subsection{PROGRAM PLANS AND PROCEDURES}

The TAC and RAC shall develop ES\&H program plans that cover work performed under their contracts. These plans need to address contract-wide and sitespecific activities. The RAC shall develop stand-alone health and safety plans as part of remedial action planning for each designated processing site and associated disposal site. Contractors shall also address specific concerns associated with subcontracted work in site/contract ES\&H documentation. Contractors shall develop environmental protection programs that meet the requirements of the UMTRA Project Environmental Protection Implementation Plan (DOE, 1994b).

Contractors shall develop written implementing plans and operating procedures for all activities where there is a significant environmental threat or health and safety risk. These plans and procedures shall also address activities necessary for quantitatively assessing radiological, industrial hygiene, and occupational safety hazards, and compliance with environmental permits and regulations. Special conditions at sites that may present potential health hazards or environmental threats will be described in these plans and procedures.

If existing site or contract ES\&H program documentation meets or exceeds the requirements of this plan, modifications to that existing program documentation are not necessary. Written operating procedures may be used to fulfill contract requirements for ES\&H program implementation plans if they appropriately address ES\&H program requirements.

\subsection{WORKER TRAINING}

Formal training shall be provided to all workers by the contractors. The training should be commensurate with the anticipated work hazards and duties, and should include discussions of the UMTRA Project occupational and radiological health and safety programs, ALARA philosophy, emergency procedures, environmental protection programs, hazardous materials on the site, and pollution prevention. Practical demonstrations should be given when appropriate. Training programs shall also provide for refresher training. While annual refresher training is recommended, specific regulatory requirements for refresher training shall be followed at a minimum.

Personnel needing access to controlled areas of UMTRA Project sites are required to receive site orientation training that addresses potential hazards on the site. Other training that may be required will depend on the work activity, including hazardous waste site training (see 29 CFR \$1910.120) and radiological worker training (see Radiological Control Manual (DOE, 1994a)). 


\subsection{RECORDS AND REPORTING REQUIREMENTS}

Each contractor shall notify the UMTRA Project Office or DOE/AL Safety Programs Division of any fatality or serious accident, as required in DOE Order 5484.1. (See also DOE Order 5000.3B on reporting). The contractor shall also be responsible for recording and reporting recordable occupational illnesses and injuries. Copies of these reports shall be forwarded to the UMTRA Project ES\&H Manager.

When worker exposure monitoring is required, all contractors shall be responsible for maintaining records of employees' exposures to radioactive or toxic materials or other potential hazards.

UMTRA Project DOE Order 5000.3B procedures require all contractors to report occurrences (such as accidents, injuries, radiation exposures, and unplanned environmental releases) to the UMTRA Project Office Manager.

Contractors having environmental monitoring responsibilities shall submit monitoring data for the UMTRA Project annual environmental report required by DOE Order 5400.1. Contractors shall also prepare reports on radioactive effluent, on-site discharges, and unplanned releases, as specified by DOE Order 5400.1. Contractors shall prepare and submit reports required by Federal, state, or local environmental permits. More detailed information on environmental reporting is found in the UMTRA Project Environmental Protection Implementation Plan (DOE, 1994b).

Each contractor shall submit a DOE Form 5484.X, "Individual Accident/Incident Report", for each occurrence for which reporting is required under DOE Order 5484.1. Reports will be submitted to the Systems Safety Development Center in Idaho with copies to the UMTRA Project ES\&H Manager.

A central file of all enforcement inspections and reports, along with violations and abatement actions, shall be maintained by contractors for inspection by the UMTRA Project Office.

\subsection{COMPLAINTS}

Employees are encouraged to report to the contractor, either directly or through their authorized employee representative, any conditions or practices that they consider detrimental to the environment or their health and safety or the public's health and safety, or which they believe are in violation of applicable ES\&H standards. Such complaints may be made verbally or submitted in writing.

Any employee, or representative of employees, who believes that a condition or practice has potential for physical or environmental harm or is in violation of an ES\&H standard, may request an inspection by filing a complaint directly with the local agency having environmental protection or health and safety responsibility, or with the DOE. 
Any employee or authorized representative of employees who believes that a hazardous condition exists with the potential to cause death or serious physical or environmental harm (an imminent danger) has the responsibility to bring the matter to the immediate attention of the appropriate contractor, supervisor, or designated official for resolution. The employee and/or authorized representative has the option to contact the local agency having jurisdiction, the DOE UMTRA Project Office, or DOE/AL by telephone, and set forth with reasonable detail the basis for his/her request for an immediate inspection.

The DOE, upon receipt of a complaint concerning alleged imminent danger or upon receipt of notice of alleged imminent danger, will immediately ascertain whether there is a reasonable basis for the allegation. If it appears to have merit, the DOE will dispatch an inspector to the workplace involved. When an immediate inspection cannot be made, the DOE will contact the contractor immediately, will gather the pertinent details concerning the situation, and, if necessary, determine whether affected employees have been removed from the danger area or direct that immediate measures be taken by the contractor to prevent injury or environmental damage. The DOE will determine whether the steps taken by the contractor are appropriate to eliminate the danger. The DOE will conduct follow-up activities, as appropriate.

If a contractor employee believes that his/her environmental, safety or health concerns regarding DOE operations will not or cannot be addressed properly through regular channels of communication, he/she may report the concern(s) using an environmental hotline operated by the Office of Inspector General of the DOE. The number is 1-800-541-1625 and is available 24 hours a day.

\subsection{POSTINGS}

Each contractor shall post DOE Form F-5480.2 (or EH F 5480.1), "Occupational Safety and Health Protection" (posters outlining contractor ES\&H responsibilities). Posters will include addresses and telephone numbers of appropriate DOE and contractor contacts who receive complaints. Each contractor shall also have available in the workplace DOE Form F-5480.4, "Occupational Safety and Health Complaint."

Contractors shall post the required forms in a sufficient number of places to permit employees working in or frequenting any portion of the workplace to observe a copy on the way to or from their place of employment. In addition, contractors shall provide a complaint form (DOE Form F-5480-4) to all employees during initial training and instruct them on its use. Contractors shall inform employees that environmental protection complaints as well as occupational safety and health complaints may be reported on that form.

\subsection{OVERSIGHT PROGRAMS}

The TAC and the RAC shall establish internal oversight teams/committees made up of ES\&H managers, and other managers and technical staff as appropriate, to 
periodically review their own and their subcontractors' operations and related procedures for compliance with ES\&H requirements. The TAC and RAC will document the results of these reviews. Reports of these reviews, including recommendations and followup activities, shall be maintained and available for review by DOE.

In addition, the Project Office, with the assistance of the TAC, shall conduct audits and surveillances of the RAC health and safety, radiological, and environmental operations and procedures. Reports of these oversight activities, including findings, recommendations, corrective actions, and follow-ups, shall be developed and made available for review by outside DOE organizations and regulatory agencies as appropriate.

\subsection{STOP WORK AND RESTART AUTHORITY}

DOE UMTRA Project employees encountering conditions or practices (including environmental releases) in any place of employment which could reasonably be expected to cause death or serious physical harm or to endanger public health (an imminent danger) have the responsibility and authority to immediately notify the worker(s) or the work supervisor of the imminent danger and the need for immediate corrective action. Any DOE UMTRA Project Office employee taking such action should then immediately notify the Project Office or DOE/AL as appropriate. Upon notification of an imminent danger, the Project Office shall ensure that corrective action is undertaken or that work is stopped until the unsafe condition is resolved.

Employees of the UMTRA Project TAC and RAC have the similar responsibility and authority at operations controlled by their employer and their employer's subcontractors. They are to immediately notify the worker(s) or the work supervisor of the imminent danger and the need for immediate corrective action. They should then immediately notify their Project Manager. Upon notification of an imminent danger, the Project Manager shall ensure that corrective action is undertaken or that work is stopped until the unsafe condition is resolved.

If a TAC or RAC employee encounters an imminent danger at a site controlled by another contractor (e.g., a TAC employee at a RAC-controlled site), that employee shall immediately notify the contractor with overall responsibility for the site. Contractor personnel at this level have the responsibility and authority to implement corrective action or stop work. 


\subsection{HEALTH AND SAFETY PLAN REQUIREMENTS}

The UMTRA Project Office has adopted the Office of Environmental Restoration's Health and Safety Plan (HASP) Guidelines, (DOE, 1994c), as the basis for the HASP requirements identified in this chapter. While this standard is specifically for 29 CFR $\$ 1910.120$ HASPs, the guidance may be used when developing HASPs for other activities or contracts if a reasonable graded-approach interpretation is applied. HASP Guidelines (DOE, 1994c) should be referred to for more detailed guidance on content of HASPs. The Occupational Safety and Health Guidance Manual for Hazardous Wastes Site Activities (DHHS, 1985) also provides general guidance that should be used when developing site-specific HASPs.

Contractor HASPs need not follow the organization used here, but all applicable UMTRA Project ES\&H Plan requirements shall be addressed in written plans or procedures. HASPS shall meet all regulatory requirements.

\subsection{INTRODUCTION}

A site- or contract-specific HASP should include a plan introduction to describe the site or contract addressed and the HASP's applicability to site or contract operations and activities. The introduction to site HASPs should include a brief description of the site's physical characteristics, relevant background information, characteristics and extent of potential contamination, and a synopsis of site operations to be performed. The introduction should also clearly state the key regulatory requirements to be met by the HASP.

\subsection{KEY PERSONNEL}

Key site or contract positions shall be listed in the HASP. This should include DOE, contractor, and subcontractor positions as appropriate. Lines of authority and functional responsibilities will be clearly indicated by organizational charts. Specific responsibilities of key positions are also to be addressed in the HASP. When personnel filling key positions are changed, the contractor's updated lists and organizational charts shall be prepared at the time of the change and posted at designated locations at the job site.

At a minimum, the HASP should identify:

- The individual and an alternate with authority to direct all site or contract activities.

- Other key operations and safety and health personnel, along with their general roles and responsibilities.

- Lines of authority. 
- Phone numbers, radio call signs, and other means of contacting key personnel.

- Interfaces and personnel in the emergency response community.

HASP Guidelines (DOE, 1994C) specify the key staff to be identified for 29 CFR $\$ 1910.120$ HASPs. Key personnel can be kept to a minimum by assigning one person the responsibilities of several positions. Responsibilities for these positions also are identified in HASP Guidelines (DOE, 1994c).

\subsection{HAZARD ASSESSMENT}

Site- or task-specific hazards must be assessed in HASPs. Though the UMTRA Project Auditable Safety Analysis (Attachment 2) addresses common hazards at UMTRA Project sites in a general manner, that document cannot be expected to replace the need for site- or task-specific hazard assessments or job safety analyses. A typical hazard assessment/job safety analysis approach includes the following basic steps:

- Identification of job, task, or operation to be assessed.

- Breakdown of the identified job, task, or operation into required steps.

- Identification of all hazards associated with each step.

- Determination of controls needed to eliminate or reduce exposures to the identified hazards.

Examples of the hazards that may be identified during hazard assessments of UMTRA Project operations include the following dangers:

- Exposures to radiation, heavy metals, silica dust, and other chemicals associated with residual radioactive material (uranium mill tailings), drill cuttings, and ground water.

- Chemical exposures associated with handling fuels, solvents, maintenance and general cleaning fluids, and laboratory and sample preparation solutions.

- Personnel injuries and equipment or property damage associated with operation of heavy equipment.

- Excavating or trenching, electrical, confined space, and slip/trip/fall hazards associated with general industry or construction work activities.

- Crushing and pinching hazards associated with operating machinery such as conveyor systems and drill rigs. 
- Vehicle accidents or spills associated with transportation of residual radioactive material.

- Biological hazards associated with poisonous plants, snakes, insects, and bloodborne pathogens.

- Exposure to noise associated with operation of heavy equipment, compressors, and other noise sources.

- Hazards caused by temperature extremes, high winds, rains, snow, electrical storms, and other weather-related conditions.

- Back injuries, muscle pulls and strains, repetitive motion, and other injuries related to poor ergonomics.

- Exposures to asbestos and other hazardous substances during demolition activities.

- Fires, explosions, and spills from poor materials storage and handling practices, especially as associated with fuels and compressed gases.

- Accidents associated with poor illumination or improper lighting, especially during night shifts.

Hazard controls that might be used are listed in order of their preference for application: elimination of the hazard, engineering controls, administrative or work practice controls, and the use of personal protective equipment (PPE). Elimination is preferred since it provides the greatest assurance of worker protection. The use of PPE requires the cooperation of the workers and training in its proper use and proper functioning; therefore, PPE is the least desirable control.

The information generated from hazard assessments and job safety analyses should be used to prepare safe work procedures specifying how jobs, tasks, or operations are to be performed while eliminating or minimizing the associated hazards. This information should also be provided to the UMTRA Project Office for use in updating the UMTRA Project Auditable Safety Analysis (Attachment 2).

\subsection{TRAINING}

Contractors' HASPs shall specify training requirements for workers, supervisors, auditors, and visitors for all site or contract activities. The means for contractors to provide training and to document completed training should be presented in HASPs. Procedures should be provided for contractors to verify that personnel have completed required training before being allowed site access. 
A prime goal of site or contract training programs should be to train workers to recognize, avoid, report, and correct health and safety hazards. Examples of the training requirements that might be specified include the following:

- 40-hour Hazardous Waste Operations and Emergency Response (HAZWOPER) training and 24-hour supervised field experience.

- 8-hour HAZWOPER supervisor training.

- HAZWOPER site safety and health coordinator training.

- 8-hour annual HAZWOPER refresher training.

- Site-specific ES\&H training.

- Emergency response training and periodic rehearsal.

- Hazard communication training.

- Radiological worker and radiological control technician training.

- Bloodborne pathogens training.

- Hazardous material shipping training.

- Lockout/tagout training.

- Asbestos abatement training.

- Nonmetal surface miner training.

\subsection{PERSONAL PROTECTIVE EQUIPMENT}

In situations where other forms of hazard control are not feasible, not adequate, or not yet implemented, PPE shall be issued by contractors to protect the health and safety of workers. Different types and combinations of PPE are required for different situations. The use of PPE can itself create significant work hazards (e.g.; heat stress, physical and psychological stress, impaired vision, reduced mobility, and communications limitations). Overprotection as well as underprotection may be hazardous and should be avoided. Therefore, PPE must be carefully selected and used to adequately protect workers.

HASPs shall contain or reference a written PPE program. Such PPE programs should address, at a minimum:

- Selection of PPE based on identified hazards. 
- Proper fitting, donning and doffing, and training in PPE use.

- Procedures for inspecting PPE prior to, during, and after use.

- Limitations of PPE, including maximum duration of use and limitations due to temperature extremes and user's medical and physical conditions.

- Maintenance, cleaning, and storage of PPE.

- Decontamination and disposal of PPE.

- Evaluation of PPE program procedures' effectiveness.

Written procedures used to implement PPE programs should comply with 29 CFR Part 1926 and the Radiological Control Manual (DOE, 1994a).

\subsection{MEDICAL PROGRAM}

Contractor's HASPs shall specify medical program requirements. These requirements shall provide for prompt first aid and medical care and, depending on requirements for the type of work and hazards involved, a medical surveillance program. Regulatory requirements for medical programs are found in 29 CFR Parts 1910 and 1926. The means for providing medical assistance and for documenting treatment shall be presented in HASPs.

\subsubsection{Medical surveillance}

Where required by CFR Part 1910 or Part 1926, contractors' HASPs shall address medical surveillance programs. Medical surveillance of workers is necessary to protect worker health, ensure fitness for duty, and comply with program and regulatory requirements. Respiratory protection, PPE, and HAZWOPER programs have medical surveillance requirements.

At a minimum, medical surveillance programs should address the following:

- Identification of employees covered by the programs.

- Frequency of medical examinations or consultations.

- Content of medical examinations or consultations.

- Information that is to be provided to physicians.

- Written opinions of physicians.

- Recordkeeping requirements.

Medical examinations are a key element of medical surveillance programs. Initial or preassignment exams establish baseline medical conditions of workers and their fitness for their assigned duties. Periodic medical exams are a means to detect changes from baseline examinations, identify physiological changes, and help ensure that workplace exposures are not adversely affecting worker 
health. Exams after injuries and illnesses verify that workers are fit to return to work. Termination exams are used to check that workers' health has not been adversely affected by their work.

\subsubsection{First aid and response to medical emergencies}

Contractors' HASPs shall reference first aid programs or describe first aid services and facilities available to workers. The level of services and type of facilities available shall be based on site or contract-specific needs. Governing factors include the following considerations:

- Number of workers covered or workers per shift.

- Type of work and hazards.

- Response time of off-site emergency medical services.

- Availability of off-site emergency care facilities.

Contractors' HASPs shall identify these factors:

- Types and qualifications of medical personnel, including first aid providers.

- Locations of first aid kits and manned medical aid stations (noted on site maps).

- Phone numbers and locations of local emergency medical services (including maps showing most direct routes) and posting requirements.

- Provisions for transportation of injured or sick workers.

- Provisions for health physics support in the event of radiological contamination of injured or sick workers.

\subsection{EXPOSURE MONITORING AND AIR SAMPLING}

Contractor's HASPs shall contain or reference exposure monitoring programs. Such programs are necessary to accurately determine the following conditions:

- Exposure levels of site or contract workers.

- Work areas with significant airborne contaminant or radiation levels.

- Potential migration of radiation or airborne contaminants from area to area or off the site.

- Feasibility of using engineering and administrative control to reduce exposures. 
- Potential modification of engineering or administrative controls or level of personal protective equipment to prevent exposures.

Contractors shall follow sound industrial hygiene and health physics principles in developing exposure monitoring and air sampling programs. Information from hazard assessments shall be used to complete radiation and general industrial hygiene surveys. Information from these surveys and experience from similar job sites shall be used to develop initial radiation and industrial hygiene monitoring and sampling plans.

Industrial hygiene monitoring by contractors is required when exposures to any hazardous material/agent are expected to average 25 percent or more of the applicable permissible exposure limit or threshold limit value. Radiation exposure monitoring by contractors is required when exposure conditions meet the criteria specified in 10 CFR Part 835. Air particulate sampling for representative radionuclides shall be performed by contractors when airborne concentrations in work areas could exceed 10 percent of a derived air concentration listed in 10 CFR Part 835. A documented approach shall be used by contractors to determine when exposure monitoring or air sampling is required.

\subsection{SITE CONTROL}

Contractors' HASPs shall have programs to control the activities and movement of people and equipment to minimize the potential for worker and public exposure to physical hazards, radiation, and other hazardous substances or agents, and to prevent unauthorized access to sites. Site control programs shall include, at a minimum, the following elements:

- Establishment of site control or exclusion zones.

- Site maps identifying locations of control or exclusion zones.

- Access control.

- Requirements for workers' "buddy system."

- Safe work practices and procedures.

- Contamination monitoring.

Site control programs shall comply with specific regulatory requirements such as those in 29 CFR \$1910.120, 10 CFR Part 835, and the Radiological Control Manual (DOE, 1994a).

\subsection{DECONTAMINATION}

Decontamination of personnel and equipment of chemical and radiological contamination shall be addressed in HASPs. At a minimum, the following decontamination elements shall be included:

- Training for all relevant personnel in general decontamination procedures. 
- Locations and layout of decontamination stations and areas.

- Required decontamination equipment.

- Procedures to protect workers from contaminants during decontamination.

- Procedures for decontamination personnel.

- Procedures for collection, staging, storage, and disposal of clothing, equipment, and other materials that have not been completely decontaminated.

Contractors shall survey all personnel, equipment, and materials exiting from radiological contamination areas to clean areas for contamination prior to being released. Contractors shall maintain records of radiological contamination surveys and use them to modify procedures to reduce the potential for the transfer of contamination to personnel and equipment. The Radiological Control Manual (DOE, 1994a) provides detailed guidance on radiological contamination control and decontamination.

Guidance on several aspects of health and safety programs that need special attention in site or contract HASPs is provided below. Sound health and safety principles should be followed in developing these programs to control associated hazards. Program elements common to all these programs include training, hazard communication, written procedures, recordkeeping, and reporting.

Depending on their breadth and importance to site/contract activities, other programs that scheduled work may require should be evaluated for more indepth treatment in HASPs. These may include spill prevention and control, electrical safety, drilling safety, confined space entry, and lockout/tagout.

\subsubsection{Radiation Protection Program}

Contractors' HASPs covering activities involving exposures to radiation shall contain or reference a radiation protection program. Such programs are necessary to ensure protection of occupational workers, the public, and the environment from exposure to radiation and radioactive materials. The program shall embrace the ALARA philosophy and include an ALARA committee to establish exposure goals and to continually assess the adequacy and sufficiency of radiation protection programs and procedures.

Personnel dosimetry and internal dose evaluations, including bioassay programs, are integral parts of a radiation protection program and contractors shall implement these procedures when the criteria specified in 10 CFR Part 835 are met. Dosimeters shall meet the requirements of the DOE Laboratory 
Accreditation Program for Personnel Dosimetry as specified in DOE Order 5480.15 .

The other elements of a radiation protection program that should be included are:

- Workplace exposure monitoring.

- Personnel monitoring.

- Hazard classification and communication.

- Facility layout and control.

- Contamination controls.

- Posting and labeling.

- Instrument maintenance and calibration.

The Radiological Control Manual (DOE, 1994a), DOE Order 5480.11, and 10 CFR Part 835 provide detailed information on radiation protection programs and the role of the ALARA committee.

\subsubsection{Industrial Hygiene Program}

Contractors' HASPS shall contain or reference an industrial hygiene program. The following elements of a industrial hygiene program should be included:

- General industrial hygiene surveys.

- Hazard identification, classification, and control measures.

- Written hazard communication program.

- Maintenance of a hazardous chemicals list and associated material safety data sheets.

- Sanitation program covering washing, toilet facilities, and drinking water.

- Handling of hazardous materials.

- Work place monitoring for airborne dust and other contaminants.

- Monitoring and control of heat and cold stress.

- Noise monitoring and hearing protection.

- Ergonomics and repetitive motion.

- Instrument maintenance and calibration. 
Contractors should use information from industrial hygiene hazard assessments and experience from similar jobs for classifying all jobs and determining potential exposures for each classification and effective exposure control measures.

Requirements for industrial hygiene programs are found in 29 CFR Part 1910 and 1926 and DOE Order 5480.10.

\subsubsection{Vehicle or Transportation Safety Program}

Contractors' HASPs shall contain or reference a vehicle or transportation safety program. The following elements of a vehicle or transportation safety program should be included:

- Accident and spill response.

- Vehicle inspection and maintenance.

- Defensive driving educational programs.

- Site traffic pattern and haul route orientation.

- Drug screening programs.

- Labeling and placarding.

- Operator history and licensing or certification status.

Requirements for vehicle or transportation safety programs are found in 29 CFR Part 1910 and 1926 and Title 49 CFR. The U.S. Department of Transportation has granted the DOE an exemption, DOT-E 10594, from certain requirements of the Title 49 CFR hazardous materials regulations for the transportation of residual radioactive materials. The provisions of this exemption shall be addressed in contractors' vehicle or transportation safety programs involving the transportation of residual radioactive materials.

\subsubsection{Construction Safety Program}

Contractors' HASPs covering construction activities, including well drilling and installation, shall contain or reference a construction safety program. The following elements of a construction safety program should be included:

- Proper operation of and behavior around operating equipment.

- Lockout/tagout program to control exposure to electricity and other energy sources.

- Good housekeeping and materials storage practices and proper use of ladders, scaffolds, safety lines, tie-offs, etc., to control or prevent slips, trips, and falls.

- Establishment and maintenance of minimum illumination levels for general site activities. 
- Safe materials hoisting, rigging, and handling.

- Proper conduct of trenching, excavation, and drilling operations.

- Proper conduct of blasting, welding, cutting, and other demolition-related operations.

- Monitoring worker behavior and training workers to recognize, avoid, report, and correct safety hazards.

- Implementation of a confined space entry program.

Requirements for construction safety programs are found in 29 CFR Parts 1910 and 1926 and DOE Order 5480.9A.

\subsubsection{Fire Protection Program}

Contractors' HASPs shall contain or reference a fire protection program. The following elements of a fire protection program should be included:

- Selection and use of portable fire extinguishers.

- Inspection and maintenance of portable fire extinguishers.

- Proper storage, dispensing, and use of flammable and combustible liquids.

- Proper installation, maintenance, and operation of electrical systems, equipment, and devices.

- Good housekeeping practices.

Many elements of a fire protection program should be part of emergency planning. Requirements for fire protection programs are found in NFPA 10 , NFPA 30, DOE Order 5480.7A, and 29 CFR Parts 1910 and 1926.

\subsection{EMERGENCY PLANNING}

Contractors shall address emergency planning and response in their HASPs. The level of emergency planning is dependent on the type of activities covered by the HASP. Emergency plans shall comply with the regulatory requirements governing the site or contract activities.

Generally UMTRA Project sites lack the dedicated organizational capability to respond to emergencies. At these sites only employee evacuation, emergency shut down, or first aid or cardiopulmonary resuscitation activities should be performed. Such sites do not need to prepare HAZWOPER emergency response plans required by 29 CFR $\$ 1910.120$, but should instead prepare emergency 
action plans (EAP) meeting 29 CFR $\$ 1910.38$ requirements. EAPs should describe actions to be taken to assure safety from fire, extreme weather conditions, chemical releases, and other emergencies, and should contain, at a minimum, the following elements:

- Emergency escape procedures and emergency escape route assignments.

- Procedures to ensure all site contractors coordinate their EAPs to prevent conflicts and confusion.

- Procedures to be followed by personnel staying behind to conduct critical operations before evacuating.

- Procedures to account for all employees after emergency evacuations are completed.

- Locations of communications equipment and descriptions of its use in emergency situations.

- Rescue and medical duties (first aid, cardiopulmonary resuscitation, etc.) for personnel assigned to perform them.

- Methods for reporting fires and other emergencies.

- Names and phone numbers of personnel and organizations to be contacted for further information or explanations of duties under the EAP.

- Alarm systems to be used to alert personnel of emergencies and evacuations.

- Training employees should receive in order to effectively carry out requirements of EAP and methods for evaluating employee knowledge of EAP.

- Fire prevention plan.

- Procedures for review and update of $\operatorname{EAP}$ (e.g., schedule, rehearsal).

Where elements of EAPs require information or data documented in other sections of HASPs, copies of the documentation should be incorporated into the EAPs. 


\subsection{ENVIRONMENTAL PROTECTION PROGRAM REQUIREMENTS}

The UMTRA Project is an environmental restoration program established to clean up and control uranium mill tailings and other associated wastes from inactive uranium mill sites. Contractors shall accomplish this work in an environmentally sound manner to eliminate current and potential hazards associated with these tailings. The UMTRA Project Office has established environmental protection programs that will protect, maintain, and where necessary, restore environmental quality, minimize potential threats to public health and the environment, and comply with environmental regulations and DOE policies. UMTRA Project contractors shall comply with these programs, which are described in detail in the UMTRA Project Environmental Protection Implementation Plan (DOE, 1994b) and associated program plans.

\section{$5.1 \quad$ ENVIRONMENTAL COMPLIANCE}

\subsubsection{NEPA Compliance}

Prior to the start of remedial actions, the TAC shall prepare NEPA documentation for UMTRA Project activities. TAC proposed actions will be evaluated to determine the level of NEPA documentation required.

Environmental impact statements or environmental assessments, as appropriate, shall be prepared by TAC that examine the impact of the proposed actions and alternatives. Remedial action may not proceed until the NEPA documentation has been approved by the DOE.

Other NEPA-related documentation required by DOE policy shall also be prepared in accordance with DOE Order 5440.1E and 10 CFR Part 1021.

\subsubsection{Permit Compliance}

UMTRA Project contractors shall procure all necessary Federal, state, tribal, and local environmental permits. All work performed shall be in compliance with required permits and applicable environmental regulations. All required records shall be kept and reports shall be filed in accordance with permits conditions.

Permits usually required for UMTRA Project site surface remedial action activities include those under National Pollutant Discharge Elimination System and National Emission Standards for Hazardous Air Pollutants requirements issued by Federal or state agencies. If UMTRA Project activities will affect regulated wetlands, Section 404 permits shall be obtained from the U.S. Army Corps of Engineers. Federal and state agencies may also require permits for activities that impact endangered or threatened species or critical habitat or cultural resources. State and local agencies also typically administer permit programs covering activities such as land use changes, haul road construction, highway access, noise control, and well construction or abandonment. 


\subsection{ENVIRONMENTAL MONITORING}

To ensure environmental protection, an environmental monitoring program shall be developed for each UMTRA Project site that conforms to DOE Orders 5400.1 and 5400.5, and the UMTRA Project Environmental Monitoring Plan (DOE, 1992a). Site environmental monitoring programs shall enable detection of all significant releases of either radiological or chemical contaminants during remedial action and after disposal.

Meteorological data, including wind and precipitation patterns, should be obtained prior to remedial action to support NEPA document and remedial action plan preparation. During remedial action, meteorological data shall be collected as required by environmental permits. These data shall be used to support environmental monitoring activities.

Contractors shall conduct environmental monitoring at all processing sites and disposal sites during remedial actions. Additionally, at large vicinity properties, they shall conduct grab sampling to determine whether a monitoring program is warranted at these properties. Data collection at the sites requiring monitoring shall be done prior to construction to characterize the preremedial action environment and the extent of any existing contamination. Contractors shall conduct monitoring during remedial action to estimate potential exposure to the nearby population and the surrounding environment, to comply with environmental permits, to allow continuing assessment of the environmental protection program, and to detect unplanned releases and their effects. Contractors will conduct postremedial action monitoring at processing sites to verify completion of the remedial action. Monitoring shall also be performed in accordance with the long-term surveillance program established for each disposal site.

Each site's environmental monitoring program shall be designed to monitor the following elements:

- Radiological and nonradiological particulate concentrations in air.

- Radon concentrations in air, surface water, and ground water.

- Radiological and nonradiological contaminants in surface water, ground water, and soil where applicable.

The justification for the contractors' choices of environmental sampling methodologies and locations shall be documented for each site's environmental monitoring program. The UMTRA Project Environmental Monitoring Plan (DOE, 1992a), The UMTRA Project Outdoor Radon Monitoring Plan (DOE, 1990), and the UMTRA Project Ground Water Monitoring Plan (DOE, 1992b) contain detailed descriptions of the monitoring requirements. 
Additional requirements may result from environmental permits required for the remedial action activities at processing and disposal sites, e.g., monitoring of point source and stormwater discharges and environmental noise.

\subsection{SPECIAL ENVIRONMENTAL PROGRAMS}

Special environmental protection programs required by DOE Order 5400.1 shall be developed.

\subsubsection{Ground Water Protection Management Program}

UMTRA Project contractors shall implement the UMTRA Project Ground Water Protection Management Program Plan (DOE 1993) which addresses the types of information required to develop a site-specific water resources protection strategy for each UMTRA Project site. The plan also describes the requirements for the preservation and protection of ground water resources at UMTRA Project sites.

\subsubsection{Waste Minimization/Pollution Prevention Awareness Program}

UMTRA Project contractors shall implement the UMTRA Project Waste Minimization and Pollution Prevention Awareness Program Plan (DOE, 1994d) which addresses UMTRA Project requirements for source reduction, waste minimization, and pollution abatement. It specifies specific responsibilities, goals, and key programs elements.

The RAC shall develop site-specific plans or procedures covering waste management activities at UMTRA Project sites to ensure that all applicable elements of the UMTRA Project plan are implemented.

\subsection{ANNUAL ENVIRONMENTAL REPORT}

At the end of each calendar year, UMTRA Project contractors shall submit information on all their environmental compliance issues and any environmental monitoring data they have collected during the year as required by ES\&H polices for incorporation into an annual environmental report. The submittal shall provide a summary and interpretation of the information collected.

The TAC shall coordinate the preparation of the annual UMTRA Project environmental report, and ensure it meets the requirements of DOE Order 5400.1. This report shall be prepared in a manner that clearly communicates the results of the UMTRA Project's environmental protection programs to the general public. 


\subsection{LIST OF CONTRIBUTORS}

The following individuals contributed to the preparation of this report.

\begin{tabular}{ll}
\hline Name & Contribution \\
\hline A. Vollmer & Document coordinator \\
$\begin{array}{l}\text { M. Kinney, C. Pettengill," } \\
\text { A. Vollmer }\end{array}$ & $\begin{array}{l}\text { Primary authors } \\
\text { B. Young," "R. Cornish," }\end{array}$ \\
$\begin{array}{l}\text { M. Miller, L. Baldwin," J. Isham," } \\
\text { L. Ross, R. Beethe, M. Bradshaw }\end{array}$ & \\
R. Woodward & Document review \\
L. Sanchez & Text processing \\
\hline
\end{tabular}

MK-Ferguson

"DOE-UMTRA 


\subsection{REFERENCES}

DOE (U.S. Department of Energy), 1994a. Radiological Control Manual, DOE/EH-0256T, Revision 1, U.S. Department of Energy, Office of Environment, Safety, and Health, Washington, D.C.

DOE (U.S. Department of Energy), 1994b. UMTRA Project Environmental Protection Implementation Plan, DOE/AL/62359-79, Rev. 1, U.S. Department of Energy, UMTRA Project Office, Albuquerque Operations Office, Albuquerque, NM.

DOE (U.S. Department of Energy), 1994c. Health and Safety Plan (HASP) Guidelines, DOE Limited Standard DOE-EM-STD-5503-94, U.S. Department of Energy, Office of Environmental Restoration, Washington, D.C.

DOE (U.S. Department of Energy), 1994d. UMTRA Project Waste Minimization and Pollution Prevention Awareness Program Plan, DOE/AL/62350-144, Rev. O, U.S. Department of Energy, UMTRA Project Office, Albuquerque, NM.

DOE (U.S. Department of Energy), 1993. Groundwater Protection Management Program Plan, DOE/AL/62350-92, U.S. Department of Energy, UMTRA Project Office, Albuquerque Operations Office, Albuquerque, NM.

DOE (U.S. Department of Energy), 1992a. UMTRA Project Environmental Monitoring Plan, UMTRA-DOE/AL-150129.0000, U.S. Department of Energy, UMTRA Project Office, Albuquerque Operations Office, Albuquerque, NM.

DOE (U.S. Department of Energy), 1992b. Groundwater Monitoring Program Plan, U.S. Department of Energy, UMTRA Project Office, Albuquerque Operations Office, Albuquerque, NM.

DOE (U.S. Department of Energy), 1990. Outdoor Radon Monitoring Plan for the UMTRA Project Sites, UMTRA-DOE/AL-150225.0000, U.S. Department of Energy, UMTRA Project Office, Albuquerque Operations Office, Albuquerque, NM.

DHHS (U.S. Department of Health and Human Services), 1985. Occupational Safety and Health Guidance Manual for Hazardous Waste Site Activities, DHHS Publication No. 85-115. National Institute of Occupational Safety and Health/Occupational Safety and Health Administration/U.S. Coast Guard/U.S. Environmental Protection Agency, Washington, D.C.

NFPA (National Fire Prevention Association), 1994. National Fire Codes, National Fire Protection Association, Quincy, MA. 


\section{CODE OF FEDERAL REGULATIONS}

10 CFR Part 1021. Compliance with National Environmental Policy Act; U.S. Department of Energy.

10 CFR Part 835. Occupational Radiation Protection, U.S. Department of Energy.

29 CFR Part 1926. Safety and Health Regulations for Construction, Occupational Safety and Health Administration.

29 CFR Part 1910. Occupational Safety and Health Standards, Occupational Safety and Health Administration.

40 CFR Part 192. Health and Environmental Protection Standards for Uranium and Thorium Mill Tailings, U.S. Environmental Protection Agency.

49 CFR. Transportation, Title 49, Code of Federal Regulations. U.S. Department of Transportation.

\section{DOE ORDERS}

Order 5000.3B, Occurrence Reporting and Processing of Operations Information, Change 1, July 2, 1993, U.S. Department of Energy, Washington, D.C.

Order 5400.1. General Environmental Protection Program, Change 1, June 29, 1990, U.S. Department of Energy, Washington, D.C.

Order 5400.5. Radiation Protection of the Public and the Environment, Change 2, January 7, 1993, U.S. Department of Energy, Washington, D.C.

Order 5440.1E, National Environmental Policy Act Compliance Program, November 10, 1992, U.S. Department of Energy, Washington, D.C.

Order 5480.7A, Fire Protection, February 17, 1993, U.S. Department of Energy, Washington, D.C.

Order 5480.9A, Construction Project Safety and Health Management, April 13, 1994, U.S. Department of Energy, Washington, D.C.

Order 5480.10, Contractor Industrial Hygiene Program, U.S. Department of Energy, Washington, D.C.

Order 5480.11, Radiation Protection for Occupational Workers, Change 3, June 17, 1992, U.S. Department of Energy, Washington D.C.

\footnotetext{
- Unless otherwise indicated, the most current versions of CFRs are applicable. 
Order 5480.15, DOE Laboratory Accreditation Program for Personal Dosimetry, December 14, 1987, U.S. Department of Energy, Washington, D.C.

Order 5484.1, Environmental Protection Safety, and Health Protection Information Reporting Requirements, Change 7, October 17, 1990, U.S. Department of Energy, Washington, D.C. 
ATTACHMENT 1

REGULATIONS APPLICABLE TO THE UMTRA PROJECT 


\section{ATTACHMENT 1}

REGULATIONS APPLICABLE TO THE UMTRA PROJECT

(Based on review of final regulations issued through October 1994.)

10 CFR Part 40

10 CFR Part 707

10 CFR Part 820

10 CFR Part 835

10 CFR Part 1021

10 CFR Part 1022

29 CFR Part 1910

29 CFR Part 1926

29 CFR Part 1960

30 CFR Part 48

30 CFR Part 56

36 CFR Part 800

40 CFR Part 50

40 CFR Part 61

40 CFR Part 110

40 CFR Part 112

40 CFR Part 122
CODE OF FEDERAL REGULATIONS*

Domestic Licensing of Source Material

Workplace Substance Abuse Programs at DOE Sites

Procedural Rules for DOE Nuclear Activities

Occupational Radiation Protection

Compliance with National Environmental Policy Act

Compliance with Floodplain/Wetlands Environmental Review Requirements

Occupational Safety and Health Standards

Safety and Health Regulations for Construction

Basic Program Elements for Federal Employee Occupational Safety and Health programs

Training and Retraining of Miners

Safety and Health Standards - Surface Metal and Nonmetal Mines

Protection of Historic and Cultural Properties

National Primary and Secondary Ambient Air Quality Standards

National Emission Standards for Hazardous Air Pollutants

Discharge of Oil

Oil Pollution Prevention

EPA Administrated Permit Programs: The National Pollutant Discharge Elimination System

\footnotetext{
- Unless otherwise indicated, the most current versions of CFRs are applicable.
} 
40 CFR Part 125

40 CFR Part 136

40 CFR Part 192

40 CFR Part 230

40 CFR Part 241

40 CFR Part 260

40 CFR Part 261

40 CFR Part 262

40 CFR Part 263

40 CFR Part 268

40 CFR Part 280

40 CFR Part 300

40 CFR Part 302

40 CFR Part 355

40 CFR Part 370

40 CFR Part 372

40 CFR Part 403

40 CFR Part 761

40 CFR Part 1500

40 CFR Part 1501
Criteria and Standards for the National Pollutant Discharge Elimination System

Guidelines Establishing Test Procedures for the Analysis for Pollutants

Health \& Environmental Protection Standards for Uranium and Thorium Mill Tailings

Section 404(b)/1) Guidelines for Specifications of Disposal Sites for Dredge or Fill Materials

Guidelines for the Land Disposal of Solid Wastes

Hazardous Waste Management System: General

Identification and Listing of Hazardous Waste

Standards Applicable to Generators of Hazardous Waste

Standards Applicable to Transporters of Hazardous Waste

Land Disposal Restrictions

Technical Standards and Corrective Action Requirements for Owners and Operators of Underground Storage Tanks

National Oil and Hazardous Substances Pollution Contingency Plan

Designation, Reportable Quantities, and Notification

Emergency Planning and Notification

Hazardous Chemical Reporting: Community Right-to-Know

Toxic Chemical Release Reporting: Community Right-to-Know

General Pretreatment Regulations for Existing/New Sources of Pollution

Regulations for Use and Commerce of Polychlorinated Bipheny/s Manufacturing Processing, Distribution in Commerce and Use Prohibitions

National Environmental Policy Act (NEPA)

NEPA and Agency Planning 
40 CFR Part 1502

40 CFR Part 1503

40 CFR Part 1504

40 CFR Part 1505

40 CFR Part 1506

40 CFR Part 1507

40 CFR Part 1508

43 CFR Part 2800

49 CFR Part 40

49 CFR Part 107

49 CFR Part 171

49 CFR Part 172

49 CFR Part 173

49 CFR Part 177

49 CFR Part 383

49 CFR Part 385

49 CFR Part 387

49 CFR Part 390

49 CFR Part 391

49 CFR Part 392

49 CFR Part 393

49 CFR Part 394

49 CFR Part 395
Environmental Impact Statement

Commenting

Predecisional Referrals to Council of Proposed Federal Actions Determined to be Environmentally Unsatisfactory

NEPA and Agency Decision Making

Other Requirements of NEPA

Agency Compliance

Terminology and Index

Right-Of-Way, Principles and Procedures

Procedures for Transportation Drug Test Program

Hazardous Material Program Procedures

Hazardous Material Information, Regulations, and Definitions

Hazardous Material Tables and Communications Regulations

Hazardous Material Shippers General Requirements

Hazardous Material Carriage by Public Highway

Commercial Drivers License Standards: Requirements and Penalties

Safety Fitness Procedures

Minimum Levels of Financial Responsibility for Motor Carriers

Federal Motor Carrier Safety Regulations: General

Qualifications for Drivers

Driving of Motor Vehicles

Parts and Accessories Necessary for Safe Operation

Notification and Reporting of Accidents

Hours of Service of Drivers 
49 CFR Part 396

49 CFR Part 399

Order 1230.2

Order 1324.2A, Chg.1

Order 1324.3, Chg.1

Order 1324.5A

Order 1324.6, Chg.1

Order 1330.1D

Order 1360.1B

Order $1360.2 B$

Order $1360.3 \mathrm{C}$

Order 1360.4B

Order 1540.1A

Order 1540.2, Chg.1

Order $3790.1 \mathrm{~B}$

Order 4330.2D

Order 4330.4B, Chg.4

Order 4700.1, Chg.1

Order 5000.3B, Chg.1

Order 5300.1C

Order 5400.1, Chg.1

Order 5400.2A, Chg.1
Inspection, Repair, and Maintenance

Employee Safety and Health Standards

\section{DOE ORDERS}

American Indian Tribal Government Policy

Records Disposition

Files Management

Records Management Program

Automated Office Electronic Recordkeeping

Computer Software Management

Acquisition and Management of Computing Resources

Unclassified Computer Security Program

Information Technology Standards

Scientific and Technical Computer Software

Material Transportation and Traffic Management

Hazardous Materials Packaging for Transport-Administrative Procedures

Federal Employee Occupational Safety and Health Program

In-House Energy Management

Maintenance Management Program

Project Management System

Occurrence Reporting and Processing of Operations Information

Telecommunications

General Environmental Protection Program

Environmental Compliance Issue Coordination 
Order 5400.4

Order 5400.5, Chg.2

Order 5440.1E

Order 5480.1B, Chg.5

Order 5480.3

Order 5480.4, Chg.4

Order 5480.5

Order 5480.7A

Order 5480.8A, Chg.1

Order 5480.9A

Order 5480.10

Order 5480.11, Chg.3

Order 5480.15

Order 5480.17

Order 5480.19, Chg.1

Order 5480.20, Chg. 1

Order 5480.29

Order 5480.31

Order 5482.1B, Chg.1

Order 5484.1, Chg.7
Comprehensive Environmental Response, Compensation and Liability Act Requirements

Radiation Protection of the Public and the Environment

National Environmental Policy Act Compliance Program

Environmental, Safety, and Health Program for DOE Operations

Safety Requirements for the Packaging and Transportation of Hazardous Materials, Substances and Waste

Environmental Protection, Safety, and Health Protection Standards

Safety of Nuclear Facilities

Fire Protection

Contractor Occupational Medical Program

Construction Safety and Health Program

Contractor Industrial Hygiene Program

Radiation Protection for Workers

DOE Laboratory Accreditation Program for Personnel Dosimetry

Site Safety Representatives

Conduct of Operations Requirements for DOE Facilities

Personnel Selection, Qualification Training and Staffing Requirements at DOE Reactor/Non-Reactor Nuclear Facilities

Employee Concerns Management Program

Startup and Restart of Nuclear Facilities

Environmental, Safety, and Health Protection Appraisal Program

Environmental Protection, Safety, and Health Protection Information Reporting Requirements

Quality Assurance 
Order 5820.2A

DOE/EH-256T

DOE/EV-0043

DOE/ID-10500

DOE N 5480.5

DOE N 5400.9
Radioactive Waste Management

\section{DOE STANDARDS}

U.S. DOE Radiological Control Manual

Standard on Fire Protection for Portable Structures

Hoisting and Rigging Manual

Imposition of Proposed Nuclear Safety Requirements

Sealed Radioactive Source Accountability

NATIONAL FIRE PROTECTION ASSOCIATION NATIONAL FIRE CODE

NFPA 1

NFPA 10

NFPA 30

NFPA 37

NFPA 70

NFPA 79

NFPA 101

SEN-35-91
Fire Prevention Code

Standard for Portable Fire Extinguishers

Flammable and Combustible Liquids Code

Standard for the Installation and Use of Stationary Combustion Engines and Gas Turbines

National Electrical Code

Electrical Standard for Industrial Machinery

Code for Safety to Life from Fire in Buildings and Structures

\section{SECRETARY OF ENERGY NOTICE}

Nuclear Safety Policy

\section{AMERICAN NATIONAL STANDARDS INSTITUTE STANDARDS}

ANSI/ASME B15.1

ANSI N323

ANSI N42.17B
Safety Standard for Mechanical Power Transmission Apparatus Radiation Protection Instrumentation Test and Calibration

Performance Specifications for Health Physics Instrumentation - Occupational Airborne Radioactivity Monitoring Instrumentation 
ANSI Z136.1

ANSI Z358.1

EO 11593

EO 11988

EO 11990

EO 12088

DOT-E 10594

DE-4004-83AL24546

DOE GM04-85AL26037

Albuq. City Ordinance

Chap. VIII, Article IX

2 CCR $\S 402$

2 CCR $\$ 601-4$

2 CCR $\$ 601-1$

5 CCR $\$ 1001-10$

5 CCR $\$ 1003-6$

5 CCR $\$ 1002-7$

5 CCR $\$ 1003-2$
Safe Use of Lasers

Emergency Eyewash and Shower Equipment

\section{EXECUTIVE ORDERS}

Protection and Enhancement of Cultural Environment

Floodplain Management

Protection of Wetlands

Federal Compliance with Pollution Control Standards

\section{OTHER APPLICABLE REQUIREMENTS}

Department of Transportation Exemption to DOE for Transportation of Uranium Mill Tailings

DOE/Bureau of Land Management UMTRA Agreement

Memorandum of Understanding DOE/Nuclear Regulatory Commission

Sewer Use and Wastewater Control Ordinance

\section{COLORADO CODE OF REGULATIONS}

Division of Water Resources

Rules and Regulations of the State of Colorado Department of Transportation Pertaining to Transport Permits for the Movement of Extra-Legal Vehicles or Loads

State Highway Access Code

Regulation No. 8: Control of Hazardous Air Pollutants

Guidelines on Individual Sewage Disposal Systems

Sewage and Storm Sewers

Certification of Water Treatment Plan and Wastewater Treatment Plan Operators 
UMTRA PROJECT

5 CCR §1002-20

Pretreatment Regulations

6 CCR $\$ 1007-1$

Radiation Control

6 CCR $\$ 1007-5$

Underground Storage Tanks

6 CCR $\$ 1007-3$

Hazardous Waste

6 CCR $\$ 1007-2$

Solid and Hazardous Waste Disposal Sites and Facilities

7 CCR $\$ 1101-14$

Underground Storage Tanks

7 CCR $\$ 1101-8$

Standards for Excavation

8 CCR $\$ 1507-7$

Rules and Regulations Concerning Hazardous Material Route Designation 
ATTACHMENT 2

UMTRA PROJECT

AUDITABLE SAFETY ANALYSIS 


\section{EXECUTIVE SUMMARY}

The U.S. Department of Energy (DOE) Uranium Mill Tailings Remedial Action (UMTRA) Project Office used conventional postulation criteria plus barrier and target analysis techniques to prepare an auditable safety analysis for the UMTRA Project. The safety and health hazards for UMTRA Project activities are primarily associated with construction. Inherent risks for UMTRA Project activities arise from operating heavy equipment, working with radioactive material and hazardous chemicals, being exposed to electricity and other energy sources, and storing flammable or combustible liquids.

The results of this auditable safety analysis indicate that all safety hazards of an appreciable nature at UMTRA Project sites are being successfully mitigated through use of appropriate barriers and controls. This determination is supported by observation of site practices, interviews with site and project personnel, verification of performance-based training, and reviews of project documentation. The results of this analysis also support the classification of UMTRA Project remedial action sites as radiological facilities in addition to demonstrating the adequacy and sufficiency of site programs and procedures. 


\section{TABLE OF CONTENTS}

Section

Page

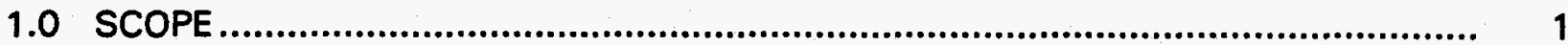

2.0 APPLICABLE STATUTES, RULES, AND DEPARTMENTAL ORDERS $\ldots \ldots \ldots \ldots \ldots \ldots \ldots \ldots . . . . . . . . . .2$

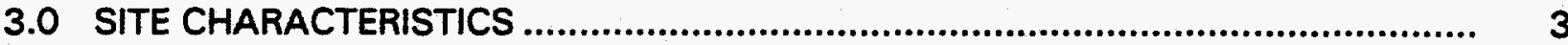

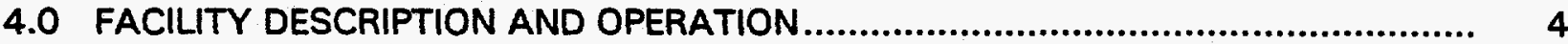

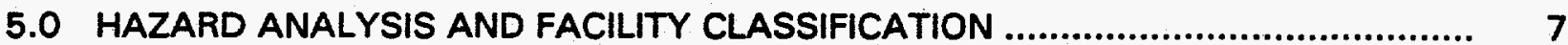

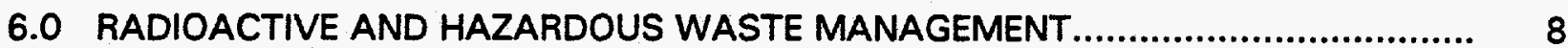

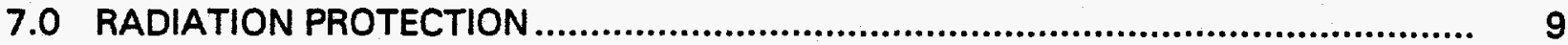

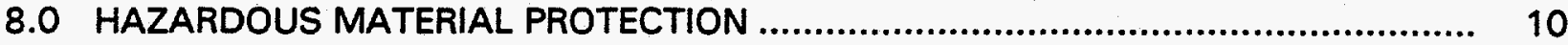

9.0 ANALYSIS OF NORMAL, ABNORMAL, AND ACCIDENT CONDITIONS ................. 11

9.1 Operation of heavy equipment ............................................................ 11

9.2 Exposure to energized equipment....................................................... 12

9.3 Fire protection............................................................................ 12

9.3.1 Mobile support structures......................................................... 13

9.3.2 Construction equipment ....................................................... 13

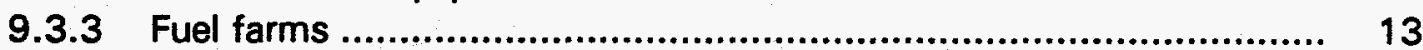

9.3.4 Maintenance yard................................................................... 14

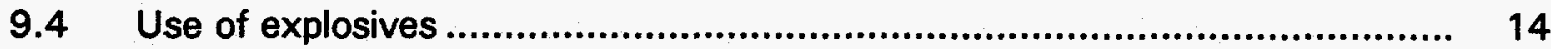

9.5 Exposure to chemicals ................................................................. 15

9.6 Operation of drilling equipment .......................................................... 15

9.7 Operation of conveyor systems ......................................................... 16

9.8 Conduct of unique and nonroutine tasks......................................... 17

9.9 Consideration of external accidents.................................................. 17

10.0 MANAGEMENT, ORGANIZATION, AND INSTITUTIONAL SAFETY PROVISIONS ...... 18

10.1 DOE UMTRA Project Office ................................................................ 18

10.2 RAC Albuquerque Project Office (APO) ................................................. 18

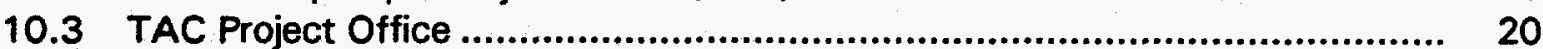

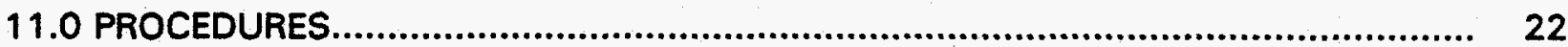

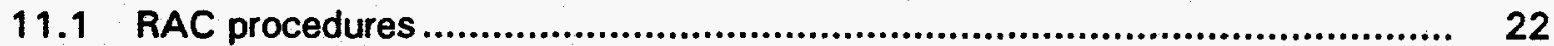

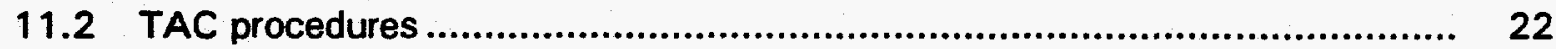

11.3 Subcontractor procedures ............................................................... 22

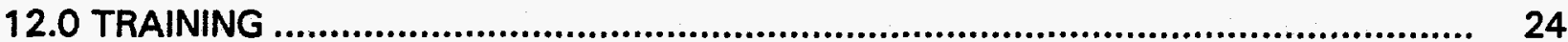


TABLE OF CONTENTS (Continued)

Section

Page

13.0 HUMAN FACTORS

13.1 Control panels

13.2 Repetitive motion.

13.3 Human and machine interaction........................................................... 26

13.3.1 Decontamination pads ............................................................. 26

13.3.2 Conveyor systems................................................................. 26

13.3.3 Drilling equipment.............................................................. 27

14.0 INITIAL TESTING, IN-SERVICE SURVEILLANCE, AND MAINTENANCE ................. 28

15.0 DERIVATION OF TECHNICAL SAFETY REQUIREMENTS ............................... 31

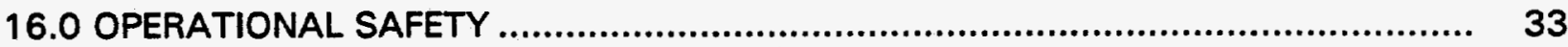

16.1 Operations organization and administration........................................ 33

16.2 Shift routines and operating practices .............................................. 34

16.3 Control area activities ...................................................................... 34

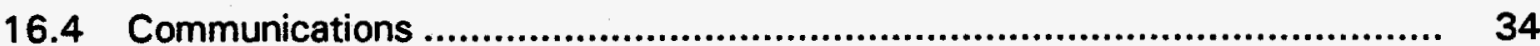

16.5 Control of on-shift training ................................................................ 34

16.6 Notifications and reporting practices ................................................ 35

16.6.1 Oral notifications ................................................................ 35

16.6.2 Written reports................................................................. 35

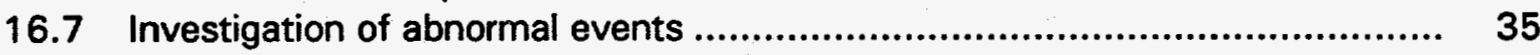

16.8 Control of equipment and system status ........................................ 36

16.8.1 Status change authorization and reporting ................................. 36

16.8.2 Equipment deficiency identification and documentation .................. 36

16.8.3 Work authorization and documentation .................................... $\quad 36$

16.8 .4 Alarm status .................................................................... $\quad 36$

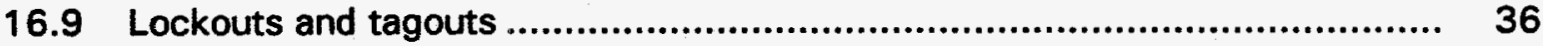

16.9.1 Lockout and tagout implementation ...................................... 37

16.9.2 Periodic inspections ............................................................ 37

16.9.3 Caution tags .................................................................... 37

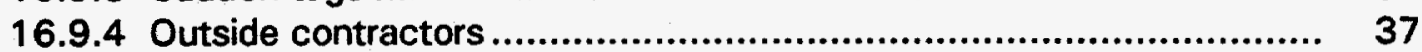

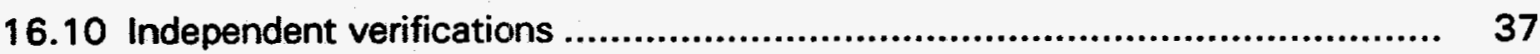

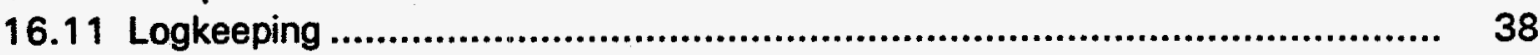

16.12 Operations turnover ...................................................................... 38

16.13 Operations aspects of facility chemistry and unique processes................... 38

16.14 Required reading ......................................................................... 38

16.15 Timely orders to operators ............................................................. 38

16.16 Control of operations procedures .................................................... 39

16.17 Operator aid postings....................................................................... 39

16.18 Equipment and pipe labeling ............................................................... 39

16.19 TAC field operations ............................................................... 39

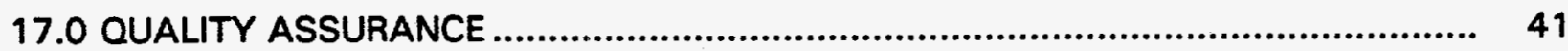




\section{TABLE OF CONTENTS (Continued)}

Section

Page

18.0 EMERGENCY PREPAREDNESS.

19.0 PROVISIONS FOR DECONTAMINATION..

43

20.0 BIBLIOGRAPHY 


\section{ACRONYMS}

Acronym

ALARA

ANSI

APO

DOE

DOE/AL

EM-451

ES\&H

ESHOE

MK-F

NEPA

NFPA

PRID

RAC

RRM

S/RID

TAC

UMTRA

\section{Definition}

as low as reasonably achievable

American National Standards Institute

RAC Albuquerque Project Office

U.S. Department of Energy

DOE Albuquerque Operations Office

DOE Headquarters, Office of Environmental Restoration, Office of Southwestern Area Programs, Off-Site Division

environment, safety, and health

ES\&H Operating Envelope

MK-Ferguson Company

National Environmental Policy Act

National Fire Protection Association

Preliminary Requirements Identification Database

Remedial Action Contractor

residual radioactive material

Standards/Requirements Identification Database

Technical Assistance Contractor

Uranium Mill Tailing Remedial Action 


\subsection{SCOPE}

The Uranium Mill Tailings Remedial Action (UMTRA) Project Office prepared this auditable safety analysis using U.S. Department of Energy (DOE) guidance prescribed in DOE-STD-102792, DOE-EM-STD-5502-94, DOE Orders 5481.1B and 5480.23. Relevant sections of these orders and standards are discussed in the body of this document along with supporting UMTRA Project protocols, plans, and procedures. The scope of this document was based upon the hazard proportionality of UMTRA Project site operations, complexity of site operations and processes, and life cycle considerations.

The majority of potential hazards discussed deal with site programs coordinated by MK-Ferguson Company (MK-F), the prime UMTRA Project surface Remedial Action Contractor (RAC). Two areas of Jacobs Engineering Group, the UMTRA Project Technical Assistance Contractor (TAC), site operations have also been included: operation of drilling equipment and water sampling activities.

Other areas of TAC site activities, radon sampling activities and conduct of ES\&H audits, were found not to have significant hazards that meet the postulation criteria for this document. Radon sampling activities consist of exchanging passive radon detectors from monitoring stations at or in the vicinity of the site. No equipment or tools are required to perform audits or radon sampling nor are TAC personnel exposed to any appreciable hazards during these activities.

This document contains discussions on the following elements:

- Site operations, including relevant equipment.

- DOE 5480.23 safety analysis topics.

- Hazards associated with operations.

- Controls in place to mitigate hazards.

- Governing documents and procedures.

- Determination of adequacy and sufficiency of controls and procedures. 


\subsection{APPLICABLE STATUTES, RULES, AND DEPARTMENTAL ORDERS}

While actual regulations, rules, and DOE Orders applicable to individual sites may vary depending on site-specific equipment, the UMTRA Project Office has determined that the regulations listed in Attachment 1 of the UMTRA Project Environment, Safety, and Health (ES\&H) Plan effectively control UMTRA Project activities. The list only contains state regulations for the state of Colorado since the majority of surface remedial action activities were in Colorado when this document was prepared.

The listing of applicable regulations is reviewed by UMTRA Project contractors for each site activity to ensure that all site operations and regulatory issues are addressed. This review is conducted using the Preliminary Requirements Identification Database (PRID) element of the UMTRA Project ES\&H Operating Envelope (ESHOE) system. The PRID element generates a report of the completed review process and identifies all regulatory documents reviewed in addition to defining which regulatory documents are applicable to the site. This process allows site reviews to be conducted in a consistent and timely manner. This process also allows existing safety documentation to be readily compared to regulations determined to be applicable for site activities.

Since 1992, over 1600 regulatory documents have been reviewed by UMTRA Project contractors for applicability to the UMTRA Project. The review process is an ongoing activity with the results documented in the PRID. The DOE UMTRA Project Office participates in the review process and provides concurrence of the completed PRID.

Applicable regulatory documents for UMTRA Project site activities are comprised of DOE Orders and standards, Titles 10, 29, 30, 40, and 49 of the Code of Federal Regulations (CFR), state regulations, and supporting codes and standards, including American National Standards Institute (ANSI) and National Fire Protection Association (NFPA) documents.

UMTRA PROJECT DOCUMENTATION: Relevant documentation includes UMTRA Project Environment, Safety, and Health Plan; Environment, Safety, and Health Regulatory Implementation Plan; and site-specific PRIDs. Based on review of these documents, the UMTRA Project Office has determined that applicable statutes, rules, and DOE Orders have been adequately identified. 


\subsection{SITE CHARACTERISTICS}

The 24 UMTRA Project sites are located in 10 states with the majority in the southwestern United States. These sites are former uranium processing sites contaminated with residual radioactive materials (RRM), uranium mill tailings and other processing site wastes contaminated with tailings. Most sites are located near, or immediately adjacent to, a river or tributary. During initial project planning activities, site boundaries are defined and placed on site drawings. Site descriptions include public exclusion areas, access control, meteorology and climatology, topographical considerations, population centers, utility interfaces, and local highways or roads. Detailed site descriptions and characteristics are contained in site-specific National Environmental Policy Act (NEPA) documents, remedial action plans, and health and safety plans.

Site characterization typically consists of drilling bore holes and ground water monitoring wells with concurrent or subsequent sample collection to determine the extent of RRM contamination. Further surveys determine the characteristics of abandoned chemicals and selected building materials and equipment. Initial characterization of existing wastes and building materials suspected of containing hazardous constituents is performed by a subcontractor certified in hazardous material handling prior to demolition activities commencing. In addition, radiological surveys determine the nature and extent of radiological contamination. These characterizations establish the baseline level of contamination and are included in the remedial action plans and are provided to potential subcontractors in contract bid documents.

During the disposal cell selection process for each site, evaluation of relevant threats to the environment determines the optimum disposal cell location. Factors included in this evaluation process are meteorological, geological, and hydrological issues, including the potential for earthquakes, floods, thunderstorms, high winds, and ground water contamination. Results of these evaluations are contained in NEPA documents and remedial action plans.

UMTRA PROJECT DOCUMENTATION: Relevant documentation includes site-specific NEPA documents, remedial action plans, and health and safety plans. Based on review of these documents, the UMTRA Project Office has determined that UMTRA Project sites have been adequately characterized. 


\subsection{FACILITY DESCRIPTION AND OPERATION}

The remedial action process for an abandoned uranium mill site generally consists of site characterization, demolition of mill structures, construction of an engineered disposal cell, movement of tailings and debris, and site restoration. Prior to remedial actions, sites are fenced, temporary offices and other support structures are erected, and decontamination facilities are installed.

The demolition (Phase I) and construction (Phase II) programs include removal, storage, and disposal of RRM and other wastes. Phase I operations primarily involve demolition of old mill buildings and size reduction of discarded equipment and support structures. Phase II operations can primarily be characterized as earth/debris-moving activities and disposal cell construction. To perform these operations, a wide variety of heavy construction equipment is used in conjunction with portable tools and haul vehicles.

All UMTRA Project sites require containment of RRM in a single location and protection of the final disposal cell configuration by placement of a protective cover. Stabilization and control of the RRM is performed within the confines of the abandoned site or at a hydrologically and geologically suitable disposal location. Disposal cell construction requires the RRM to be stabilized to meet the public health and environmental protection standards in 40 CFR Part 192 by achieving a minimum 90 percent compaction. A layer of clay is placed over the RRM to inhibit radon emission and infiltration of water. Generally a rock armor cover is placed over the clay to prevent intrusion and degradation of the clay layer by flora or fauna, and to protect the underlying layers from erosive forces. At some sites the disposal cell may be topped with a cover of nonintrusive native vegetation.

While the operations at most UMTRA Project sites are similar, there are some variations in site operations and practices depending on the disposal option selected. Disposal options fall into three categories: stabilization in place, stabilization on site, or relocation. These three categories generally have the following operational configurations:

\section{Stabilization in place}

The main mill tailings pile is reconfigured in place to meet final slope and erosion protection requirements. Demolition debris and windblown contamination are placed in the main tailings pile. Tailings relocation is kept to a minimum.

\section{Stabilization on site}

Most mill tailings and debris are relocated to a disposal location within existing site boundaries to address environmental or engineering concerns. Most hauling is confined to the controlled areas of the former processing site. 


\section{Relocation}

The mill tailings are transferred from the former mill processing area to an off-site disposal cell location. Relocation is usually performed using semi-tractor trailer trucks, which are loaded at the processing site and hauled to the disposal cell on public roads or dedicated haul roads.

Because of their similarities, most UMTRA Project sites have the following operational features:

- Endloaders: Load stockpiled demolition debris into haul trucks for relocation to the disposal cell.

- Scrapers: Transport the mill tailings within the disposal cell area and to clean RRM from areas with windblown contamination.

- Bulldozers: Relocate mill tailings, including establishing final grade and subsequent placement of riprap rock material.

- Motorgraders: Perform final grading of mill tailings and radon barrier material for final disposal cell configuration and also used for road maintenance.

- Mobile cranes: Perform assorted facets of demolition, construction, and maintenance activities.

- Trackhoes: Perform demolition activities, often with shear or hammer attachments. Trackhoes can also be used for excavation of tailings and subpile contamination.

- Backhoes: Perform numerous activities, including demolition, trenching, and relocation of rock.

- Haul trucks: Transport and deposit demolition debris and tailings in the disposal cell area.

- Compactors: Compact tailings after placement in the disposal cell.

- Water trucks: Spray water to reduce wind blown mill tailings, provide dust suppression to inactive areas of site, assist in achieving optimum moisture content for compaction, and provide general dust abatement for overall site.

- General purpose vehicles: Move personnel and small equipment and tools around the site. These vehicles usually consist of passenger cars, pick-ups, carryalls, vans, and small maintenance trucks.

- Maintenance areas and buildings: Store supplies and replacement parts and shelter mechanics who perform equipment maintenance. "Butler" type buildings and semitractor trailers are usually used for these purposes. These areas and buildings are usually located near construction equipment parking areas. 
- Management support structures: Shelter management personnel, supervisors, and support personnel for day-to-day activities such as office work, analytical facilities, and lunch/break areas. These structures are normally single-wide, mobile trailers.

- Access control trailers: Shelter site personnel who monitor workers and suppliers entering and leaving controlled areas. Entrance into a controlled area is documented and the appropriate protective clothing is issued. When personnel exit a controlled area, all protective clothing is removed and a whole body radiological frisk is performed and documented. Dosimeters are also issued and retrieved at the access control trailer.

- Decontamination pads: Provide to decontaminate haul trucks and other equipment prior to exiting the controlled area, using a low-pressure, high-volume system. Other decontamination techniques such as scraping, brushing, wet sandblasting, steam cleaning, and high-pressure water spray are used when necessary.

- Holding ponds: Contain water supply for decontamination pads and include a recycling system to remove solids. These holding ponds also contain runoff from site drainage systems and supply water for dust abatement on the site.

- Diesel generators: Provide electrical power $(120 \mathrm{~V})$ for operation of air compressors, water pumps, and powered hand tools at remote locations and within the site boundaries.

- Portable light towers: Supplant ambient light when it is not sufficient.

- Explosives: Excavate rock for cell placement cover, during initial configuration of the disposal cell, for size reduction of waste ore rock size prior to placement in the cell, and to demolish assorted water towers and buildings.

UMTRA PROJECT DOCUMENTATION: Relevant documentation includes site-specific remedial action plans and subcontractor procedures and work plans. Based on review of these documents, the UMTRA Project Office has determined that they contain adequate descriptions of facilities and operations to allow effective safety and health programs to be developed. 


\subsection{HAZARD ANALYSIS AND FACILITY CLASSIFICATION}

UMTRA Project sites are classified as "radiological facilities" pursuant to the hazard categorization and analysis techniques specified in DOE Standard DOE-STD-1027-92. The hazard classification process included the following:

- a safety and health hazard analysis to determine the quantity of potentially releasable RRM needed to exceed nuclear hazard Category 3 threshold quantities;

- postulation of credible release criteria or events that could initiate releases of RRM; and

- calculation of releases based on the postulation events.

The quantities of RRM required to trigger a Category 3 classification ranged from 240 to 5800 cubic yards. Based on evaluations of release scenarios involving high winds, heavy rains, and transportation accidents, the hazard classification analysis concluded that there were no credible release scenarios for UMTRA Project sites that would result in unmitigated releases of RRM in quantities exceeding Category 3 threshold quantities. However, these scenarios could potentially result in releases of radioactive material in excess of the reportable quantities listed in 40 CFR Part 302, Table 302.4, Appendix B.

Furthermore, the quantities of hazardous material potentially releasable from UMTRA Project sites are below 29 CFR $\$ 1910.119$ and 40 CFR Part 355 thresholds due to the limited quantities of these materials stored on site.

UMTRA PROJECT DOCUMENTATION: Relevant documentation is established in the letter from F. Bosiljevac, DOE UMTRA Project, to D. Mathes, EM-451, of March 16, 1994. Based on review of the analyses addressed in this document, the UMTRA Project Office has determined that sufficient analyses were performed to properly classify UMTRA Project sites as "radiological facilities" as defined in DOE-STD-1027-92 and DOE-EM-STD-5502-94. 


\subsection{RADIOACTIVE AND HAZARDOUS WASTE MANAGEMENT}

The UMTRA Project's remedial actions involve disposal of RRM, i.e., uranium mill tailings and other wastes associated with the processing sites including radioactively contaminated hazardous waste. The RRM is managed by placing it in UMTRA Project disposal cells in accordance with remedial action plans. RRM, the only type of radioactive waste managed on the UMTRA Project, is regulated under 40 CFR Part 192. While limited quantities of hazardous materials are used at UMTRA Project sites, nonradiological hazardous wastes are not generated. The UMTRA Project has also implemented a waste minimization and pollution prevention awareness program to identify potential waste streams and to prevent or minimize the generation of radioactive, hazardous, or other solid wastes at UMTRA Project sites.

All wastes on the UMTRA Project are thoroughly characterized to identify any radiological or nonradiological hazards. All identified hazards are communicated to workers through the site hazard communication program. All radioactively contaminated hazardous wastes requiring disposal at UMTRA Project sites are handled by certified hazardous waste management subcontractors. These subcontractors are required to perform all work in accordance with approved 29 CFR $\$ 1910.120$ health and safety plans. If any nonradiological hazardous wastes were generated, similar controls would be imposed.

UMTRA PROJECT DOCUMENTATION: Relevant documentation includes UMTRA Project Waste Minimization and Pollution Prevention Awareness Program Plan; RAC Waste Minimization and Pollution Prevention Program Plan; health and safety plans, and remedial action plans. Based upon a review of these documents, the UMTRA Project Office has determined that the protocols used to manage radioactive and hazardous waste are adequate. 


\subsection{RADIATION PROTECTION}

Workers and the public are protected from risks associated with radiation and radioactive materials through a comprehensive radiation protection program developed and implemented by UMTRA Project contractors. This radiation protection program is developed to comply with DOE Orders 5400.5 and 5480.11, 10 CFR Part 835, and DOE/EH-0256T. The program addresses topics such as work place monitoring, environmental monitoring, contamination controls, posting and labeling, documentation, training, facility design and control, and accidents and emergencies. Implementation of radiation protection programs at UMTRA Project sites is routinely evaluated during internal audits and surveillances.

A mission of the radiation protection program is to make every reasonable effort to maintain occupational, environmental, and public radiation exposure as low as reasonably achievable (ALARA). To this end, an ALARA program has been implemented for all UMTRA Project site activities. The premise of the ALARA program is based on the assumption that the risk associated with radiation exposure is directly proportional to the dose incurred and that there is no threshold dose below which there is no risk. The program addresses topics such as administrative exposure controls; training; internal audits, self assessments, and evaluations; optimization and cost-benefit methodology; radiological design review and procedure review; radiation work permits; radiological performance and awareness; and documentation and record keeping. In addition, an ALARA committee has been established to set exposure goals and to oversee and review applicable elements of radiation protection programs and procedures.

UMTRA PROJECT DOCUMENTATION: Relevant documentation includes RAC Radiation Protection Program; Health Physics Operations and Radiation Protection Procedures Manual; Health Physics Instrumentation Procedures Manual; Health Physics Administrative and Transportation Procedures Manual. Based upon a review of these documents, the UMTRA Project Office has determined that the protocols used to limit personnel exposure to radiation are adequate. 


\subsection{HAZARDOUS MATERIAL PROTECTION}

Each UMTRA Project site has implemented a hazard communication program under the site industrial hygiene program to address all chemicals used on site. The program complies with the requirements of 29 CFR $\$ 1910.1200$ and 29 CFR \$1926.59. Each hazardous chemical received on site must have a material safety data sheet on file at each designated work location prior to the chemical being issued for use. Copies of material safety data sheets are readily accessible to employees. Site personnel also are trained in the proper use of chemicals.

Each UMTRA Project site also has designated hazardous material storage areas. These hazardous material storage areas vary in size, commensurate with volumes at the site. Appropriate storage containers and cabinets are selected based on the nature of the materials being stored. All hazardous materials are labeled in accordance with 29 CFR $\$ 1910.1200$ regarding chemical constituents, warning labels, handling instructions, and flammability characteristics. Access to these hazardous material storage areas is limited to qualified personnel.

In addition, initial site characterization of existing wastes and building materials suspected of containing hazardous constituents is performed by a subcontractor qualified in hazardous material handling prior to demolition activities commencing. The results of these characterization efforts are included in the remedial action plans and provided to potential subcontractors in bid documents. Chemical hazards related to these materials are also communicated to site personnel.

UMTRA PROJECT DOCUMENTATION: Relevant documentation includes RAC Industrial Hygiene Manual and site health and safety plans. Based upon a review of these documents, the UMTRA Project Office has determined that the hazardous material protection programs developed for UMTRA Project sites are adequate. 


\subsection{ANALYSIS OF NORMAL, ABNORMAL, AND ACCIDENT CONDITIONS}

Principal accident scenarios during Phase I demolition activities are those associated with operation of heavy equipment, cranes, and trucks; elevated work locations; demolition of existing mill structures (stacks, towers, buildings, etc.); and limited use of explosives. These accident scenarios address those activities relating to construction programs including exposure to energized equipment, flammable materials, chemicals, hazardous substances, and fires. Phase I activities are usually complete within 120 days and involve limited personnel, approximately 20 to 40 workers.

Principal accident scenarios for Phase II construction activities are those associated with heavy construction equipment and haul trucks. These accident scenarios address those activities relating to construction programs including exposure to energized equipment, flammable materials, chemicals, hazardous substances, and fires. Accident scenarios could also include hazards associated with conveyor systems or drilling equipment. Phase II activities are usually completed within 2 to 4 years and typically involve 200 to 400 site workers.

Failure of existing barriers for any of the nine scenarios discussed below would not lead to a release of RRM that would present an unacceptable radiological hazard to site workers or the public. Credible release scenarios involving high winds, heavy rains, and transportation accidents were examined as part of the hazard classification process for UMTRA Project sites. Because of the relatively low activity of RRM, no credible releases were identified that would result in a radiological hazard.

\subsection{OPERATION OF HEAVY EQUIPMENT}

Bulldozers, trackhoes, and cranes are used in the demolition of former mill site structures and buildings. Bulldozers, scrapers, and endloaders are used to relocate the mill tailings throughout the processing and disposal sites. Bulldozers are also used to locate the final rock cover. Scrapers are used for cell construction and placement of cover material. Dump trucks and endloaders are used to load and transport demolition debris to a designated area for subsequent sizing and placement in the disposal cell. Endloaders are also used to transfer the mill tailings into the haul trucks. Haul trucks enter and exit sites while hauling tailings from processing to disposal sites.

The amount of this equipment is based upon site-specific requirements. All sites have established routes defined for operation of construction equipment to control traffic patterns. Any changes in the traffic patterns are discussed with site personnel prior to implementation of the change. Haul truck drivers are provided with extensive orientation regarding haul route parameters prior to commencing haul activities.

- Hazards: Primary hazards associated with this equipment are striking of other construction vehicles or personnel resulting in injury or death of personnel or damage to equipment. Secondary hazards are falls from this equipment while personnel are ascending or descending, resulting in injuries. 
- Controls: Exposure to primary and secondary hazards for this equipment are controlled through administrative programs and barrier devices.

Administrative controls are in the form of site-specific procedures, tailgate meetings, physical separation of vehicles while in operation, and sitespecific training. Barriers include designated traffic lanes, traffic control signs, use of roll-over protection systems, and earthen berms to control traffic flow.

\subsection{EXPOSURE TO ENERGIZED EQUIPMENT}

Only limited energized electrical circuits are present during Phase I site activities. Power lines to existing site structures are terminated prior to demolition and all buildings are checked for energized wires. Electrical power is supplied during Phase II activities. Electrical voltage at UMTRA Project sites can be up to 480 volts, with step-down transformers used as needed. Other energy sources can include hydraulic and pneumatic systems. All work on energized systems is controlled through a formal lockout/tagout program.

- Hazards: Primary hazards are collapse of hydraulic or pneumatic systems resulting in shock, dismemberment, or death of personnel. Secondary hazards are the exposure of personnel to electrical hazards in the immediate area and contact with unrestrained (whipping), high-pressure hydraulic and pneumatic control lines resulting in injury of personnel.

- Controls: Exposure to primary and secondary hazards of energized equipment are controlled through both administrative programs and barrier devices. Administrative controls for lockout/tagout activities are though use of lockout/tagout procedures. These procedures are established at the RAC Project Office level and augmented with site-specific procedures developed by the RAC or site subcontractors. All lockout/tagout procedures require the use of locks and tags and require that all residual energy sources be relieved prior to work activities commencing. Barriers take the form of locking devices (with accompanying tags) and blocking devices for use on systems that can not be relieved of stored energy. In addition, safety cable restraints are used for high-pressure hoses.

\section{FIRE PROTECTION}

The risk of fires is present throughout all phases of remedial action. While each site's fire hazard characteristics may vary, all sites have potential fire hazards. Site areas with highest risk of fires are mobile support structures, construction equipment, fuel farms, and maintenance yards. Quantities and types of fire protection equipment required to support UMTRA Project site activities are based upon the fire hazard analysis techniques defined in DOE Order 5480.7 and applicable NFPA codes (primarily NFPA 10 and NFPA 30). 


\subsubsection{Mobile support structures}

Mobile support structures, usually single-wide trailers, are used for numerous functions at UMTRA Project sites, including limited parts storage, office space, and access control.

- Hazards: Primary hazards are fires from ignition of paper in trash cans or working areas resulting in death or injury to personnel. Secondary hazards are damage to facilities and loss of records.

- Controls: Administrative controls include site procedures prohibiting smoking in mobile structures and daily walkthrough inspections of mobile structures to monitor for poor housekeeping practices. Location of each portable fire extinguisher is clearly identified for all occupants of the mobile structure. All mobile support structures are provided with portable fire extinguishers as directed by 29 CFR Part 1926.

\subsubsection{Construction equipment}

Gasoline or diesel powered construction equipment is used throughout all UMTRA Project sites.

- Hazards: Primary hazards are fires from ignition of fuel or lubrication fluids resulting in injury to personnel. Secondary hazards are personnel exposures to chemicals and damage to equipment.

- Controls: Administrative controls include site-specific training and procedural requirements for placement of at least one portable fire extinguisher in each piece of equipment. All construction equipment is provided with a minimum of one readily accessible portable fire extinguisher.

\subsubsection{Fuel farms}

The majority of UMTRA Project sites have on-site fuel farms for storing and dispensing gasoline, diesel fuels, oils, and lubricants. These flammable and combustible materials are stored in lined and bermed aboveground storage tanks located at appropriate distances from site operations.

- Hazards: Primary hazards are fires and explosions involving large volumes of flammable or combustible materials resulting in death or injury to personnel. Secondary hazards are personnel exposures to chemicals and damage to equipment or the environment.

- Controls: Exposures to primary and secondary hazards for transfer of flammable and combustible materials are controlled through both administrative programs and barrier devices. Administrative controls for 
operation of fuel farms exist through use of site-specific procedures developed by RAC site personnel. Placarding is in place at all fuel farms regarding minimum distance for parking vehicles, no smoking requirements, and operation of fuel dispensing equipment. Site-specific training is provided to all personnel operating fuel farm equipment. Barriers used are remote location, earthen berms, and hazard-class electrical systems placed around fuel farms. Depending on site equipment, fuel storage tanks may also be equipped with fusible links to provide immediate fuel shutoff in the event of a fire. All fuel farms are provided with portable fire extinguishers. Size and quantity of the fire extinguishers is based upon quantities of flammable and combustible liquids stored. In addition, portable fire extinguishers are placed to meet the spacing requirements of 29 CFR $\$ 1926.152$ and NFPA 10.

\subsubsection{Maintenance yard}

Each UMTRA Project site has a designated area where maintenance activities are performed on construction equipment.

- Hazards: Primary hazards are fires due to ignition of fuels and related lubrication fluids contained in construction equipment being serviced resulting in death or injury to personnel. Secondary hazards are personnel exposures to chemicals and damage to equipment.

- Controls: Administrative controls include site procedures and training provided to all maintenance personnel regarding hazards associated with working around flammable/combustible liquids. In addition, signs are clearly posted identifying areas where smoking or open flames are not allowed. All maintenance yards are provided with portable fire extinguishers. Size and quantity of the fire extinguishers is determined by volumes of fire load, using the criteria provided in 29 CFR $\$ 1926.152$ and NFPA 10.

\subsection{USE OF EXPLOSIVES}

Depending on the type of site or existing geological formations, explosives have certain applications: to excavate rock for cell placement cover; to establish initial configuration of the disposal cell; to demolish old mill buildings and other structures; and to reduce bulk of RRM prior to placement in the cell.

- Hazards: Primary hazards are death or dismemberment of personnel due to concussion forces and projectile impact. Secondary hazards are injury of personnel or damage of vehicles or equipment due to falling debris or projectile impact.

- Controls: Exposure to primary and secondary hazards is controlled through administrative programs. Administrative controls are in the form of preplanning meetings with site personnel, preblast meetings, and 
coordination of site personnel work schedules to reduce personnel at the site not involved in the blasting operations. In addition, explosives are only handled by certified specialists and blasting operations are performed using dual-actuated controllers to prevent inadvertent detonation.

\subsection{EXPOSURE TO CHEMICALS}

All chemicals are stored in designated areas at each UMTRA Project site. Volumes and hazardous constituents of these chemicals can vary on a site-by-site basis, contingent on actual chemicals used. With the exception of fuels and motor oil, only limited quantities ( $<100$ gallons) are usually kept on site at any one work location. During laboratory analyses and water sampling, RAC and TAC personnel use small quantities of chemicals to process and preserve samples and clean equipment.

- Hazards: The primary hazard is exposure to hazardous chemicals through inhalation, skin or eye contact, and ingestion resulting in injury or illness.

- Controls: Exposure to chemical hazards is controlled through both administrative programs and barrier devices. All UMTRA Project sites have RAC project-wide and site-specific procedures for handling and use of chemicals. All site personnel are instructed in proper use of chemicals and associated hazards and on the use and location of material safety data sheets and eye wash stations. Depending on site configuration, barriers can include secured storage trailers, designated storage areas, and cabinets. TAC water samplers are required to use appropriate personal protective equipment and storage containers. These procedures are supported by hazard communication programs.

\subsection{OPERATION OF DRILLING EQUIPMENT}

Drilling equipment is used at UMTRA Project sites for drilling of holes to geologically characterize the subsurface soils and to collect soil samples for radiological and chemical characterization. Wells are also drilled to provide construction water and for use during ground water characterization and monitoring. Drilling activities are performed by qualified subcontractors with TAC or RAC personnel providing technical oversight of drilling operations and collection of samples.

- Hazards: Primary hazards are electrocution of personnel due to drilling equipment contacting overhead or underground power lines; injury or death of personnel by contact with rotating equipment or drill rig tip-overs; and injury or death of personnel due to drilling equipment piercing underground piping systems containing flammable or combustible liquids or gases. Secondary hazards are injury of personnel due to exposure to hazardous and radioactive constituents in soils and ground water from the drill hole or well; contact with unrestrained (whipping) high pressure hydraulic or pneumatic lines due to line failure; falling equipment or components caused by hoisting 
wire rope failures; and falls from drill rig mast while performing maintenance or set-up activities.

- Controls: Exposure to primary and secondary hazards of drilling equipment is controlled through both administrative programs and barriers. Contractor and subcontractor procedures have been developed for use of drilling equipment. Drilling equipment to be placed adjacent to overhead power lines maintains the minimum clearance requirements specified by 29 CFR $\$ 1910.333$. During the drilling site selection process, potential drilling sites are evaluated for presence of underground utilities, subsurface contaminants, and stability of soils. A complete inspection and walkaround of the drilling rig is performed prior to each day's activities commencing. Barriers include guards placed around drill stems and safety cable restraints on all high pressure hoses. Protection is provided to maintenance personnel through use of fall restraint systems when working on elevated portions of the drill rig.

\subsection{OPERATION OF CONVEYOR SYSTEMS}

Conveyor systems are in place at selected UMTRA Project sites for loading of the mill tailings, dispersal of the mill tailings at the disposal cell, and separation of rock material for subsequent disposal cell cover placement.

- Hazards: Primary hazards of conveyor systems are pinching or crushing of personnel resulting in injury or death. Secondary hazards are personnel being struck by falling rock material or personnel falling from high elevations of conveyor systems while performing maintenance or lubrication activities.

- Controls: Exposure to primary and secondary hazards of conveyor systems is controlled through both administrative programs and barrier devices. All conveyors used at UMTRA Project sites are operated by subcontractors and have site-specific procedures developed and approved prior to use. RAC personnel participate in adequacy and sufficiency reviews of these procedures prior to implementation. Protective overhead shields are in place to prevent falling debris from striking personnel who walk under elevated conveyor systems. Protection is provided to maintenance personnel through use of fall restraint systems when working on elevated conveyor systems. In addition, all conveyor systems have numerous lockout/tagout barriers in place. Depending on configuration, these barriers can include fencing to prevent unauthorized entry, guarding at all pinch point areas, and wire rope restraints to prevent personnel from falling onto a conveyor belt surface. Where required, emergency pull cords are also provided along the length of a conveyor system to permit the system to be immediately shut down. 


\subsection{CONDUCT OF UNIQUE AND NONROUTINE TASKS}

Day-to-day site operations are augmented by job safety analyses for unique activities tasks not addressed in other safety review processes. Job safety analyses are developed by the contractor or subcontractor with assistance provided by RAC site personnel as required. The activity-specific job safety analyses identify tasks to be performed, potential hazards associated with the tasks, and barriers and controls in place to mitigate the hazards. As a minimum, all activity-specific job safety analyses are approved by the subcontractor site manager and safety and health supervisor prior to use. In addition, each site subcontractor is required to develop site-specific procedures to address work the subcontractor is responsible for performing. These procedures are reviewed by the RAC or TAC as appropriate for adequacy and sufficiency prior to use.

\subsection{CONSIDERATION OF EXTERNAL ACCIDENTS}

From a facility safety perspective, credible external accident scenarios at UMTRA Project sites are manmade and primarily limited to operation of commercial vehicles. These external events are controlled through posting of speed limits, exclusion zones, and vendor orientation. Site access of commercial delivery drivers is limited to only management trailer areas and not to the processing site or disposal cell areas where the mill tailings are located or construction equipment is operating.

External manmade accident scenarios in the vicinity of UMTRA Project sites are also limited to those safety issues associated with operating semi-tractor trailer or dump trucks on public thoroughfares. These types of accidents are controlled through site-specific procedures identifying haul route, defensive driving education programs for drivers of haul trucks, driver orientation of haul route, and appropriate signs and postings. Local citizens are advised of haul truck activities including hours of operation, routes, and volume of trucks. In the event of an accident where a haul truck released the total load of mill tailings, the public would not be exposed to significantly elevated levels of radiation.

UMTRA PROJECT DOCUMENTATION: Relevant documentation includes RAC Construction Environment, Safety, and Health Management Plan; RAC site-specific emergency preparedness procedures, health and safety plans, and hazard communication plans; UMTRA Project Technical Assistance Contractor Environment, Safety and Health Management Plan; Albuquerque Operations Manual; and UMTRA Project Water Sampling Handbook. Site subcontractors generate sitespecific procedures on an as-needed basis, contingent upon their designated work activities. Based upon a review of these documents, the UMTRA Project Office has determined that the existing controls used to limit target exposure to the hazards discussed in this section are adequate. This determination also is based upon UMTRA Project Computerized Accident Information Reporting System reports showing that all UMTRA Project sites had a 1993 total recordable rate of 2.6 medical treatment cases per 100 employees, less than half the DOE-wide national rate of 6.0 cases per 100 for construction activities. 


\subsection{MANAGEMENT, ORGANIZATION, AND INSTITUTIONAL SAFETY PROVISIONS}

All UMTRA Project participants have established safety and health organizations. The structure of these organizations is at the project-wide level as well as the site-specific level. Organizations' descriptions are provided in project safety and health documents and clearly identify lines of authority and functional responsibilities for appropriate organizational units.

\subsection{DOE UMTRA PROJECT OFFICE}

The UMTRA Project Office has day-to-day responsibility for planning, coordinating, and conducting remedial actions at UMTRA Project sites. To achieve its mission in a manner that protects public health and safety and ensures the safety and health of workers, the UMTRA Project Office has implemented the UMTRA Project ES\&H Plan. Within the Project Office, the Engineering and Construction Group has line management responsibility for ES\&H compliance and the Technical Support Group is responsible for ES\&H guidance and oversight. The UMTRA Project ES\&H Plan provides a detailed list of Project Office responsibilities. The DOE Albuquerque Operations Office (DOE/AL) also provides matrix ES\&H support to the Project Office and has an independent oversight role.

\section{Technical Support Group}

The Technical Support Group issues ES\&H guidance to contractors, develops ES\&H policy and implementation plans, and provides ES\&H oversight of contractors through numerous audits, surveillances, readiness assessments, and site visits. The Technical Support Group also is responsible for administering the UMTRA Project Federal Employee Occupational Safety and Health Program, which covers DOE UMTRA Project employees. The DOE ES\&H Manager, assisted by the Radiation Protection Manager, chairs the UMTRA ES\&H Committee, which addresses ES\&H issues affecting the UMTRA Project.

\section{Engineering and Construction Group}

The Engineering and Construction Group is responsible for all site activities including contract requirements with responsibility for individual sites assigned to DOE site managers. The DOE site managers routinely visit the sites before, during, and after remedial action and meet with RAC and TAC management and site personnel to discuss site issues, including subcontractor performance and health and safety issues. DOE site managers also serve as a points of contact with the public to discuss health and safety issues of concern.

\subsection{RAC ALBUQUERQUE PROJECT OFFICE (APO)}

The RAC, as the prime construction contractor for surface remedial action, has line management responsibility at UMTRA Project sites. The RAC APO Operations Department, through its site managers, has line management responsibility for site ES\&H compliance. The RAC APO Construction ES\&H Department is responsible for 
developing and maintaining the RAC ES\&H plans, which contains the RAC APO's implementation procedures for the ES\&H requirements, including radiation protection, set forth in the UMTRA Project ES\&H Plan. The construction ES\&H staff works with RAC site personnel to ensure consistent application of RAC ES\&H procedures, serves as a point of contact for unique issues or questions that arise at the field level, and provides internal oversight. Construction ES\&H managers also serve on the UMTRA Project ES\&H Committee.

Actual depth of each site's health and safety organization will vary, primarily due to the number of subcontractors performing work activities at the site. The general safety and health responsibilities of the RAC site organizational elements, including those of subcontractors, are outlined below.

\section{RAC site manager}

The RAC site manager is responsible for the day-to-day operation of the site, including working with the DOE site manager and RAC APO to ensure implementation of RAC procedural requirements. The RAC site manager also works closely with the subcontractor site representatives.

\section{RAC site superintendent}

The site superintendent is responsible for day-to-day coordination of site work and general oversight of all remedial activities. The site superintendent is also responsible for ensuring RAC and RAC subcontractor compliance with UMTRA Project ES\&H requirements, and coordinates corrective actions with the site ES\&H manager and site safety supervisor.

\section{RAC site ES\&H manager}

The site ES\&H manager is responsible for coordinating implementation and maintaining the site health and safety plan, including periodic review and revision. The site ES\&H manager is also responsible for tracking and maintaining all training and medical qualification records required in the site health and safety plan.

\section{RAC site safety supervisor}

Under the direction of the site ES\&H manager, the site safety supervisor serves as the primary on-site contact for safety and health issues. The site safety supervisor also assists the site superintendent with safety and health oversight of RAC and RAC subcontractor on-site operations to ensure correct field execution of the site health and safety plan.

\section{RAC site health physics manager}

The site health physics manager is responsible for implementation and maintenance of radiation protection programs. The site health physics manager also serves as 
the primary site contact for health physics issues and manages all radiation protection field staff.

\section{Subcontractor site manager}

The subcontractor site manager is responsible for the day-to-day activities of subcontractor personnel, including working with the RAC APO and the RAC site manager to ensure implementation of RAC procedural requirements.

\section{Subcontractor site safety and health representative}

The subcontractor site safety and health representative is responsible for implementation of all site safety and health issues, including establishing training requirements, preparing and reviewing site-specific procedures, orientating personnel regarding safety aspects of their work activities, and performing daily walkaround inspections of work areas.

\subsection{TAC PROJECT OFFICE}

The TAC does not have a permanent field presence at UMTRA Project sites. As a result, the TAC safety and health organization is project-based rather than sitebased. The TAC safety and health organization is responsible for the safety and health of TAC personnel and provides technical support to the DOE UMTRA Project Office during ES\&H oversight activities of the RAC. TAC ES\&H staff also serve on the UMTRA Project ES\&H Committee.

\section{TAC safety and health manager}

The TAC safety and health manager is responsible for the development and maintenance of the TAC ES\&H plan and site-specific plan supplements. The TAC safety and health manager identifies TAC safety and health training requirements, schedules training, and maintains training records of TAC personnel. The TAC safety and health manager also is the focal point for review of TAC work plans and TAC subcontractor health and safety plans and is responsible for internal safety and health oversight of TAC activities at UMTRA Project sites.

\section{Field technical representatives}

The TAC field technical representatives have TAC line management responsibilities for ES\&H compliance by TAC subcontractors such as well drillers. The field technical representatives review the subcontractors' health and safety plans and conduct safety inspections and orientation meetings before field work commences to ensure subcontractor employees are aware of the health and safety plan requirements.

UMTRA PROJECT DOCUMENTATION: Relevant documentation includes UMTRA Project Site Management Manual; Vicinity Property Management and Implementation Manual; UMTRA Project Environment, Safety and Health Plan; 
UMTRA Project Federal Employee Occupational Safety and Health Program Plan; RAC Construction Environment, Safety and Health Management Plan; UMTRA Project Technical Assistance Contractor Environment, Safety and Health Management Plan; and site-specific health and safety plans. Based upon review of the organizational structures and safety provisions discussed in these documents, the Project Office has determined that adequate safety and health programs are in place to ensure the safe conduct of UMTRA Project activities. 


\subsection{PROCEDURES}

The UMTRA Project activities are governed by procedures of three distinct organizational elements: TAC, RAC, and subcontractors. All procedures are reviewed for adequacy and sufficiency by the DOE UMTRA Project Office.

\subsection{RAC PROCEDURES}

All RAC APO procedures are developed using the RAC Project Procedure Manual protocol. Numerous RAC APO ES\&H procedures are used at the site level in lieu of site-specific procedures, particularly for radiological sampling activities. All RAC APO procedures are reviewed and approved in accordance with Project Procedure Manual protocol prior to issuance. Site personnel develop procedures to address site-specific issues on an as-needed basis. All site-specific procedures developed are reviewed and approved by appropriate RAC APO department heads, including the construction ES\&H manager, prior to use.

Examples of RAC APO procedures may be found in Project Procedures Manual; Construction Environment Safety and Health Management Plan; Industrial Hygiene Procedures Manual; Quality Assurance Program Plan; Training Procedures Manual; Occurrence Reporting and Processing System Program Manual; and Health Physics Procedures Manual.

\subsection{TAC PROCEDURES}

All TAC procedures are developed and reviewed in accordance with Albuquerque Operations Manual protocol. At a minimum, review of TAC procedures includes the responsible technical manager and the safety and health manager.

Examples of TAC procedures may be found in UMTRA Project Technical Assistance Contractor Environment, Safety, and Health Management Plan; Albuquerque Operations Manual, and UMTRA Project Water Sampling Handbook.

\subsection{SUBCONTRACTOR PROCEDURES}

Participation by subcontractors at each UMTRA Project site varies dependent upon each site contract. The number of subcontractors for each UMTRA Project site can vary depending on the work activities being performed. Each subcontractor is responsible for developing site-specific procedures or work plans to address activities that the subcontractor performs. For RAC subcontractors, the subcontractor site manager and safety and health representative are responsible for reviewing and approving all site procedures. For TAC drilling subcontractors, the drill rig operator is generally responsible for reviewing well drilling procedures. RAC and TAC personnel also review subcontractor procedures. 
Examples of subcontractor procedures include health and safety plans, hazard communication procedures; spill prevention, control, and countermeasures plans, and lockout/tagout procedures.

UMTRA PROJECT DOCUMENTATION: All procedures generated for UMTRA Project site activities meet the applicable elements of 29 CFR Parts 1910 and 1926 and relevant DOE Orders including DOE 5480.9A, DOE 5480.11, DOE 5480.19, DOE 5000.3B, and DOE 4330.4B. Based upon review of the contractor procedures referenced above, the Project Office has determined that adequate programs are in place for the development of procedures governing the conduct of UMTRA Project activities. 
Responsibility for training at UMTRA Project surface remedial action sites is divided among the RAC APO, RAC site organization, and subcontractors. Formalized training for supervisors and management positions is incorporated into training programs at the RAC APO and RAC site level. Training responsibilities are divided between the RAC project training coordinator, site training coordinator, and subcontractors.

Management training updates personnel yearly in new procedures and operations. Site managers, supervisors, engineers, and ES\&H personnel attend these training sessions. Internal training programs also exist for site workers in the fields of safety and health, health physics, hazard communication, total quality management, quality assurance, and industrial hygiene. Additionally, all management-level personnel receive training in line management and total quality management assessment to assist them in their work. There are also corporate training and outside seminars to keep personnel updated on changing standards, regulations and other professional development.

TAC personnel are not considered full-time site workers and as such are provided with site hazards orientation prior to visiting each active site. This site orientation is provided by the TAC safety and health staff and augmented by visitor training provided by RAC site personnel. Safety training for all TAC personnel is also provided through the TAC Health and Safety Department. Task training for TAC personnel is provided through TAC line management. TAC water samplers who visit inactive UMTRA Project sites are provided with task-specific hazards orientation training by their TAC manager in addition to the TAC health and safety manager.

Training programs for UMTRA Project workers meet applicable elements of 29 CFR Parts 1910 and 1926, 30 CFR Part 48, DOE 5480.11, DOE 5480.19, DOE 5000.3B, DOE 5480.20, and DOE 4330.4B.

UMTRA PROJECT DOCUMENTATION: Examples of RAC training procedures include Construction Environment, Safety and Health Management Plan; Radiation Worker Training Course; Site Worker Course Book; Total Quality Management Program; and Training Procedures Manual. TAC training procedures and requirements are in the UMTRA Project Technical Assistance Contractor Environment, Safety, and Health Management Plan and the TAC Albuquerque Operations Manual. Based upon a review of these documents, the UMTRA Project Office has determined that the training programs developed for UMTRA Project activities are adequate. 


\subsection{HUMAN FACTORS}

For UMTRA Project site activities, facility safety human factors are divided into three categories, control panels of equipment, repetitive motion hazards, and human and machine interaction risks.

\subsection{CONTROL PANELS}

Control panels for limited UMTRA Project site equipment fit this category, including primarily cabs of construction equipment, cabs of haul trucks, control panels for conveyor systems, and control panels for drilling equipment. Control panels for construction equipment, haul trucks, and drilling equipment are designed by the original equipment manufacturer. Control panels for conveyor equipment are designed by the original equipment manufacturer or site personnel as required.

- Hazards: Operator error due to control panel(s) not effectively designed or installed or else mislabeled.

- Controls: Administrative controls include manufacturer design specifications, site-specific procedures, site design reviews, and control panel orientation for site personnel operating equipment.

UMTRA PROJECT DOCUMENTATION: Relevant documentation includes original equipment manufacturer manuals. The UMTRA Project Office has reviewed these documents and determined that existing controls used to limit operator error are adequate.

\subsection{REPETITIVE MOTION}

Primary repetitive motion hazards from a safety perspective are those associated with UMTRA Project site personnel operating equipment at decontamination pad(s).

- Hazards: Fatigue is due to repetitive motion of operating wash down hoses, bending over to examine under equipment, etc. The potential for fatigue is compounded by types of personal protective equipment required, including coveralls, boots, hard hats, safety glasses, gloves, and ear plugs. Dependent on the season, use of this equipment can also present heat exhaustion hazards due to elevated temperatures.

- Controls: Administrative controls include heat stress monitors, heat/cold injury prevention training, and ergonomic review.

UMTRA PROJECT DOCUMENTATION: Relevant documentation includes RAC Industrial Hygiene Procedures Manual; Construction Environmental, Safety, and Health Management Plan; Health Physics Procedures Manual. Each site subcontractor generates site-specific procedures on an as-needed basis, contingent 
upon work activities performed. The UMTRA Project Office has reviewed these documents and determined that existing controls used to limit repetitive motion risks are adequate.

\subsection{HUMAN AND MACHINE INTERACTION}

Primary human and machine interaction risks are personnel working at decontamination pads, conveyor systems, and drilling equipment.

\subsubsection{Decontamination pads}

- Hazards: Personnel slipping on wet concrete and being struck by trucks entering or leaving a decontamination pad area. Agility of decontamination personnel is reduced by personal protective equipment required, including coveralls, boots, hard hats, safety glasses, gloves, and ear plugs.

- Controls: Administrative controls include site-specific procedures, training, and designated decontamination personnel who monitor location of site employees before trucks are allowed to move from a decontamination pad area. Barriers in the form of tire chocks are placed at the wheels of trucks during decontamination process.

UMTRA PROJECT DOCUMENTATION: Relevant documentation includes RAC Industrial Hygiene Procedures Manual; Construction Environment, Safety, and Health Management Plan; and Health Physics Procedures Manual. Each site subcontractor generates site-specific procedures on an as needed basis, contingent upon work activities performed. The UMTRA Project Office has reviewed these documents and determined that existing controls used to limit human and machine interaction risks at decontamination pads are adequate.

\subsubsection{Conveyor systems}

- Hazards: Site personnel are periodically assigned to work immediately adjacent to moving conveyor belts to remove reject material, debris, etc. Agility of personnel is reduced by personal protective equipment required, including coveralls, boots, hard hats, safety glasses, gloves, and ear plugs.

- Controls: Administrative controls include site-specific procedures and training. Barriers include protective guarding at assigned work stations and wire rope restraints to prevent personnel from being snagged by moving belts or falling onto conveyor surfaces. Where required, emergency stop pull cords and emergency stop buttons are also provided.

UMTRA PROJECT DOCUMENTATION: Each site subcontractor generates sitespecific procedures on an as-needed basis, contingent upon work activities performed. The UMTRA. Project Office has reviewed these procedures and 
determined that existing controls used to limit human and machine interaction risks at conveyor systems are adequate.

\subsubsection{Drilling equipment}

- Hazards: Personnel operating drilling equipment are placed in proximity to rotating equipment and devices, including drive shafts, pulleys, and related drive train devices. This condition presents a risk of pinching or crushing by human contact with rotating equipment and devices. Drilling activities are performed by subcontractors with the TAC responsible for coordinating the drilling effort.

- Controls: Procedures have been developed for use of drilling equipment at UMTRA Project sites. All personnel operating or working near drilling equipment are trained on the potential hazards in addition to performing a walkaround of the drilling equipment prior to performing each day's activities. Barriers are used to control hazards associated with rotating equipment and similar devices. Access controls are required when the drill stem is rotating to keep personnel away. All shafts and pulleys are guarded as required by 29 CFR $\$ 1926.307$ to prevent inadvertent contact with rotating surfaces.

UMTRA PROJECT DOCUMENTATION: Relevant documentation includes UMTRA Project Technical Assistance Contractor Environment, Safety, and Health Management Plan and Albuquerque Operations Manual; RAC Construction Environment, Safety, and Health Management Plan. Each drilling subcontractor generates site-specific procedures for drilling activities prior to drilling being performed. The UMTRA Project Office has reviewed these documents and determined that existing controls used during operation of drilling equipment to limit human and machine interaction risks are adequate. 


\subsection{INITIAL TESTING, IN-SERVICE SURVEILLANCE, AND MAINTENANCE}

The UMTRA Project has developed a maintenance management program using the gradedapproach criteria defined in DOE Order 4330.4B. The UMTRA Project maintenance management program is implemented at the site level to ensure that equipment and components can operate dependably without excessive downtime. RAC site personnel are responsible for only limited devices, namely respirators, safety monitoring equipment, and office equipment. While each site's maintenance management program can vary depending on actual equipment, components, or maintenance facility used, the majority of sites' maintenance programs have the following elements in place.

\section{Organization}

All UMTRA Project site subcontractors are responsible for maintenance of their equipment. The subcontractor typically has a maintenance supervisor who is assisted by 2 to 6 support personnel. The subcontractor maintenance supervisor is responsible for the day-to-day maintenance activities of all subcontractor equipment, including preventive, predictive, and corrective duties. RAC site personnel assist the subcontractor in developing maintenance programs and/or procedures as needed.

\section{Training}

All UMTRA Project site subcontractors are responsible for training of their maintenance personnel. New personnel usually receive this training by working directly with experienced personnel to learn required duties. All maintenance training is performance based, with the subcontractor maintenance supervisor monitoring progress of new employees.

\section{Testing}

All equipment, systems, or processes are tested in accordance with manufacturers' recommendations or site procedures.

\section{Facility condition assessment surveys}

RAC site and subcontractor personnel perform daily and weekly facility walkaround inspections to verify condition of equipment and components. Selected types of equipment (haul trucks, scrapers, conveyors, rock separators, etc.) have walkaround inspections performed before each use or daily start -up. In addition, the RAC conducts readiness reviews before initial site startup and before start-up after seasonal shutdown. The DOE also conducts readiness assessments of these reviews.

\section{Work order system}

Each site subcontractor is responsible for developing a work control system which meets the needs of equipment being serviced. RAC site personnel provide guidance on which elements need to be addressed. As a minimum, all subcontractor work order systems for maintenance activities meet applicable requirements of DOE Order $4330.4 B$ and 49 CFR Part 396. 


\section{Maintenance procedures}

Each site subcontractor determines the depth of procedures required to support maintenance activities.

\section{Preventive maintenance}

Each site subcontractor establishes a preventive program to ensure that all construction equipment, haul trucks, and supporting equipment are effectively maintained. This program is augmented with site-specific procedures as needed.

\section{Seasonal facility preservation}

The majority of UMTRA Project sites have a winter shut down program due to inclement weather. All heavy equipment is either removed from the site or winterized to prevent damage due to freezing temperatures. RAC site personnel use this period to perform equipment maintenance, receive/provide formal training, and revise procedures as needed. Environmental monitoring, limited dust abatement, and runoff control is also performed. Subcontractors also rebuild equipment and revise procedures as needed.

\section{Equipment repair history}

All RAC and subcontractor site maintenance programs are required to maintain relevant records of repairs to equipment. As a minimum, the site programs meet the applicable requirements of DOE Order 4330.4B and 49 CFR Part 396.

UMTRA PROJECT DOCUMENTATION: Relevant documentation includes RAC Construction Environment, Safety, and Health Management Plan and Transportation Requirements and Truck Inspection Plan; UMTRA Project Technical Assistance Contractor Environment, Safety and Health Management Plan and Albuquerque Operations Manual; and subcontractor-specific procedures. Based upon a review of the regulations and governing documents referenced above, the UMTRA Project Office has determined that the maintenance management program developed by the UMTRA Project to support site activities is adequate. 


\subsection{DERIVATION OF TECHNICAL SAFETY REQUIREMENTS}

In 1992, the UMTRA Project developed an "operating envelope" strategy to determine the technical safety requirements for UMTRA Project activities. This strategy identified the regulatory documents containing the technical safety requirements that met the following operating envelope criteria: confinement of RRM, hazardous material, hazardous waste, or measurement of their release to the environment; environmental and occupational safety and health of UMTRA Project personnel and the public; continued, reliable remedial actions; and physical security of UMTRA Project sites.

The operating envelope for the UMTRA Project is derived using the Standards/Requirements Identification Database (S/RID) element of the UMTRA Project ESHOE system. The S/RID contains the mandatory statements from regulations determined to meet the operating envelope criteria. While each UMTRA Project site operating envelope may vary slightly, site S/RIDs are configured using functional areas that conform to the DOE Environment, Safety, and Health Plan Configuration Guide. The UMTRA Project Office has determined that the following functional areas adequately define all safety-related activities at UMTRA Project sites.

- Configuration management.

- Engineering, design, and construction.

- Emergency preparedness.

- Operational readiness review.

- Environmental protection.

- Fire protection.

- Maintenance.

- Management systems.

- Occupational safety and health.

- Operations.

- Packaging and transportation.

- Quality assurance.

- Radiological protection program.

- Safeguards and security.

- Training.

- Environmental restoration and waste management.

- Personnel.

The applicability of these functional areas for UMTRA Project site operations is based upon reviews of site programs, decisions with TAC and RAC management personnel, and input from the DOE UMTRA Project Office. Additional information regarding appropriate operating envelope configuration and criteria was also provided by DOE/AL and DOE Headquarters EM451 personnel.

Each of these functional areas contain the relevant criteria from regulations determined to be applicable to UMTRA Project site operations. A comprehensive applicability analysis of the mandatory criteria statements from the regulations identified in the UMTRA Project PRID (see Attachment 1 of the UMTRA Project Environment, Safety, and Health Plan) was completed in 
1994 and the results entered in the S/RID. The S/RID is updated as needed to reflect latest regulatory document changes. When determining the operating envelope for an UMTRA Project site, the actual equipment and processes to be used at the site are considered in the review process to ensure that all appropriate safety related criteria have been addressed. The DOE UMTRA Project Office provides final approval for the contents of the operating envelope and is also responsible for coordinating any requests for deviations from criteria contained in the operating envelope.

As discussed previously in this document, UMTRA Project site operations and practices do not encompass activities that require conventional limiting conditions of operation, redundant safety systems, or traditional safety limit parameters. The operating envelope developed for UMTRA Project site activities addresses all safety-related issues, including training of personnel, configuration of flammable material storage areas, staffing requirements for site programs, etc.

The derivation of technical safety requirements for UMTRA Project site activities also is supported by job safety analyses that are developed for unique tasks. These safety analyses define hazards associated with the unique task, discuss barriers or controls in place to reduce personnel exposure to the hazard, provide a determination of acceptability for performing the task, and are used to train site personnel.

UMTRA PROJECT DOCUMENTATION: Relevant documentation includes Environment, Safety, and Health Regulatory Implementation Plan, S/RID, and S/RID Users Manual. Based upon review of the ESHOE system and the controls established to ensure that the system is maintained for the duration of UMTRA Project activities, the UMTRA Project Office has determined that the process used to derive technical safety requirements for UMTRA Project activities is adequate. During 1995, the ESHOE system will be applied to the UMTRA Project sites in Colorado at Naturita, Maybell, and Slick Rock, which are scheduled to begin construction during the fiscal year. 


\subsection{OPERATIONAL SAFETY}

The UMTRA Project has developed an operations organizational structure that addresses all relevant sections of DOE Order 5480.19. This organization structure has been developed for site activities, which are controlled by the RAC. The TAC is responsible for site selection, characterization and engineering-related activities and, therefore, does not require this operational organization infrastructure. The construction-oriented activities at UMTRA Project sites and the graded-approach criteria prescribed by DOE 5480.19 indicate that the elements discussed below provide effective control of UMTRA Project site operations. The conduct of TAC field operations is briefly discussed at the end of this chapter.

\subsection{OPERATIONS ORGANIZATION AND ADMINISTRATION}

Conventional operations protocols for the UMTRA Project apply only to activities and processes that the RAC APO has jurisdiction over. The RAC APO sets yearly goals for all departments. Analysis of previous goals are reviewed and updated, as necessary. RAC policies and procedures are defined in various operations manuals, including the following:

- Construction Environment, Safety, and Health Management Plan.

- Industrial Hygiene Procedures Manual.

- Quality Assurance Program Plan.

- Vicinity Property Management Implementation Plan.

- Health Physics Procedures Manual.

- Total Quality Management Program.

- Training Procedures Manual.

Each RAC site operations organization generally consists of a site manager, site superintendent, ES\&H manager, health physics manager, site engineer, and a quality supervisor. These professionals are competent and carry authority for their areas of responsibility. Additionally, the RAC places operational safety responsibility on all employees and subcontractors and holds them accountable for all phases of work under their purview.

The RAC APO has developed an internal total quality management program that assists line management in monitoring operational performance and administering their jobs. The RAC also has an extensive quality assurance program and quality control department which continuously audits the UMTRA Project. Internally, the site managers audit the site weekly by filling out the "Operation Surety Surveillance Report" and transmitting it to the Project Office.

The RAC APO has established training programs to meet the applicable requirements of 29 CFR Parts 1910 and 1926. RAC site managers, supervisors, engineers, and ES\&H personnel participate in these training programs. Training programs covering a variety of topics, including safety and health, health physics, 
hazard communication, industrial hygiene, and quality assurance, also extend to site subcontract workers.

\subsection{SHIFT ROUTINES AND OPERATING PRACTICES}

The majority of UMTRA Project sites have a single shift with a "back shift" that performs routine maintenance activities or repairs identified during the shift by the equipment operators.

Inspection is a part of normal operating procedures. Each operator is responsible for verifying that the equipment to be used is safe and in proper working condition. Before equipment is used, site personnel properly calibrate and inspect it. At this time, the status of the equipment and specified electrical components are also verified. Any defective equipment is tagged out of use. Site inspections are performed daily. These site inspections are recorded on daily log sheets.

\subsection{CONTROL AREA ACTIVITIES}

All work areas "inside the fence" of UMTRA Project surface remedial action sites are classified as radiologically controlled areas. Access to controlled areas is limited through procedures and training requirements. The control of these work areas is maintained by site health physics personnel. Access to control rooms for conveyor systems is limited to operational personnel only. Access limits for these control areas are communicated to site personnel through site training, posting and placarding.

\subsection{COMMUNICATIONS}

Communication at UMTRA Project sites is provided through use of telephones, pagers, and portable radios. Public address systems and emergency signals are not required on the UMTRA Project construction sites, because effective communication is maintained between all levels of workers by use of portable radios. There are generally no areas where radio use is prohibited. Appropriate site personnel are trained in the proper use of radios. All personnel assigned radios are also assigned identifying numbers used at the beginning of each communication. Safety-related information is also conveyed to site workers through the use of "toolbox" safety meetings, bulletin boards, signs, and flags.

\subsection{CONTROL OF ON-SHIFT TRAINING}

RAC APO and site personnel and subcontractor personnel provide appropriate training for all RAC personnel to assist them in doing their jobs properly. Level of operations training is determined by actual job requirements and job task analysis. Required training is also specified in the appropriate procedural manuals. Additional on-the-job training is provided as needed, and performance of the trainee is closely monitored by a competent supervisor. 
Prior to starting work on an UMTRA Project site, all personnel receive the Construction ES\&H Site Worker Training course. Those persons working more than 40 hours on an UMTRA Project site receive radiation worker training.

Subcontractors are required to develop training programs which meet the criteria defined in appropriate regulations and requirements prescribed by RAC APO. For example, subcontractors who employ truck drivers and heavy equipment operators must ensure that these personnel are qualified under appropriate state and federal regulations, and UMTRA Project contract requirements.

\subsection{NOTIFICATIONS AND REPORTING PRACTICES}

The UMTRA Project has implemented an Occurrence Reporting and Processing System (ORPS) program that addresses applicable requirements of DOE Order 5000.3B for reporting of emergency, unusual, or off-normal events. The UMTRA Project has prepared a project-specific interpretation of DOE 5000.3B Attachment 1, the UMTRA Project List of Reportable Occurrences, to aid project participants when categorizing reportable occurrences. All emergency, unusual, or abnormal events are reported through the DOE UMTRA Project Office to DOE Headquarters.

\subsubsection{Oral Notifications}

The RAC and TAC field personnel must report all incidents within 20 minutes of discovery to the RAC or TAC oversight office. The field personnel then begin the occurrence investigation process. The oversight office pre-categorizes the occurrence and notifies the DOE Project Office within two hours of the discovery of the occurrence. The Project Office approves the category and makes all further notifications.

\subsubsection{Written Reports}

The RAC, TAC, and DOE have instituted reporting programs for communication of all emergency, unusual, or off-normal events. Draft reports are completed at the field level and faxed to the RAC or TAC oversight office. The oversight office puts the reports in the DOE occurrence reporting format and transmits the reports to the DOE UMTRA Project Office for approval. When the report is approved, the Project Office, with support from the TAC, transmits the report through the ORPS database to DOE Headquarters.

The DOE Project Office, RAC, and TAC have prepared their own procedures for implementing the UMTRA Project ORPS program, which have been approved by the Project Office and submitted to the DOE/AL.

16.7 INVESTIGATION OF ABNORMAL EVENTS

All abnormal or unusual events are investigated and reported through the RAC APO, or TAC Project Office, to the DOE UMTRA Project Office. The Construction Environment, Safety, and Health Management Program defines how the abnormal or unusual event is to be handled and documented. Near-miss or close-call situations 
are reported to the RAC APO and investigated by RAC site management to reduce the chance of a similar incidents from occurring. The investigation is the direct responsibility of the site manager and is performed by RAC personnel and subcontractor front-line supervision. Event analysis is performed by the RAC APO and site personnel, and event trending is informally monitored.

16.8 CONTROL OF EQUIPMENT AND SYSTEM STATUS

Activities at UMTRA Project sites that meet the requirements of DOE Order 5480.19 are divided into the following elements:

\subsubsection{Status change authorization and reporting}

For each UMTRA Project site, the RAC site manager is the senior operating person and maintains a broad authority over facility operations. The RAC site manager also has status change authority over designated site operations.

\subsubsection{Equipment deficiency identification and documentation}

The RAC has developed an extensive system for each UMTRA Project site to ensure that all equipment is operable and safe. All defective equipment is indicated as outof-service by placing a "Do Not Operate," or similar, tag at the operator's station.

\subsubsection{Work authorization and documentation}

All shift activities are authorized by the RAC site manager. The RAC site manager discusses operations with the subcontractor on a daily basis, eliminating the need for written authorization. All shift variances, such additional shifts or overtime, require written approval.

\subsubsection{Alarm status}

Control panels found on UMTRA Project sites for operations such as water treatment facilities, have alarms to note if they are out of control limits. Additionally, alarms are found on some of the construction equipment. These alarms and their maintenance programs have been determined to be effective based on safety, health, and programmatic impacts.

\section{$16.9 \quad$ LOCKOUTS/TAGOUTS}

Work involving proximity to electrical services or charged pipe systems is not performed on UMTRA Project sites. Lockout/tagout programs have been implemented for all UMTRA Project sites. All systems and equipment are locked and tagged or otherwise secured in a "zero energy" state, prior to work being performed. Subcontractors augment the lockout/tagout program with individual site-specific procedures as needed. 
The lockout/tagout program developed by the UMTRA Project meets all applicable criteria defined in 29 CFR $\$ 1910.147$ and $\$ 1926.417$ and DOE Order 5480.19 and consists of the following elements:

\subsubsection{Lockout/tagout implementation}

When maintenance is required on any equipment, the equipment is isolated to prevent injury. Site personnel are not allowed to work on energized equipment, except under special provisions. Subcontractors must prepare supporting procedures to govern work on energized systems. These subcontractor procedures address applicable elements of 29 CFR $\$ 1910.147$ and DOE Order 5480.19 and are reviewed by RAC site staff for acceptability.

\subsubsection{Periodic inspections}

Daily site safety inspections, which include reviews of current lockout/tagout practices, are conducted on all UMTRA Project sites. The RAC documents these inspections weekly as required by the Construction Environment, Safety, and Health Management Plan.

\subsubsection{Caution tags}

Caution tags used at UMTRA Project sites meet the requirements of DOE Order 5480.19 and 29 CFR \$1910.147. Use and application of caution tags is limited since the majority of lockout/tagout activities require use of "Danger - Do Not Operate" tags.

\subsubsection{Outside contractors}

All personnel that enter any UMTRA Project site are indoctrinated on site hazards and must sign a document stating that they have received indoctrination for the site lockout/tagout program. Those authorized or affected subcontractors are be trained in accordance with the RAC energy source lockout/tagout procedure.

\subsection{INDEPENDENT VERIFICATIONS}

Verification of site operations is performed at several levels of independence. The RAC site ES\&H staff performs daily surveillances and inspections of site subcontractor operations. The RAC APO conducts routine independent ES\&H surveillances of site operations. In addition, the DOE ES\&H and quality assurance staff, supported by TAC ES\&H and quality assurance staff, conduct frequent independent oversight of site operations to assess compliance with ES\&H and quality requirements. Further independent verification of site operations is provided by periodical DOE/AL and DOE Headquarters appraisals, assessments, and audits. 


\subsection{LOGKEEPING}

Daily logs are kept by engineering personnel, supervisors, the site health physics manager, and the site manager on all sites. The logs contain all daily events and a history of daily operational activities. The logs are structured to convey equipment performance information in a consistent and uniform manner. The logs are kept on the site and made available to all interested parties. Weekly reports are also sent in from the engineering, safety, health physics and quality assurance departments on each site to appropriate RAC APO personnel.

\subsection{OPERATIONS TURNOVER}

Where required, turnover checklists are provided to site personnel for vehicle inspections, equipment operations, as well as ES\&H activities. The turnover checklists are reviewed by RAC and subcontractor personnel and appropriate action is taken. The turnover checklists are supported by verbal discussions between site personnel during shift changes and shift crew briefings.

\subsection{OPERATIONS ASPECTS OF FACILITY CHEMISTRY AND UNIQUE PROCESSES}

At UMTRA Project sites, water from decontamination activities usually is collected in holding tanks for reuse. This water is treated with time-release chlorine tablets or other appropriate microbiocide to inhibit the growth of harmful bacteria. Site personnel monitor the microbiocide levels to ensure that the appropriate concentrations are maintained.

When necessary, UMTRA Project sites also use water treatment plants to control the $\mathrm{pH}$ levels of site water and to radiologically decontaminate water used, before it is discharged. Where these processes occur, specific written guidelines and procedures are developed to control work activities. These procedures specify responsibilities of the personnel working in the treatment plant and appropriate training, including hazard communication training, is done for all personnel operating these waste water treatment plants. Operation of these waste water treatment plants is limited to only qualified technicians who are knowledgeable in the processes.

\subsection{REQUIRED READING}

RAC APO and site management staff define which documents and procedures must be read by personnel prior to performing work activities at the site. New materials, including revisions to existing procedures, are distributed, read, and discussed during worker "tool box" safety meetings. After winter shutdown, all site personnel are reoriented on site documents and procedures prior to performing work.

\subsection{TIMELY ORDERS TO OPERATORS}

Revisions to operational procedures are discussed with operations personnel prior to implementation. Changes of day-to-day operational activities are communicated 
though use of radios, "tool box" meetings, and direct conversation with affected operators.

\subsection{CONTROL OF OPERATIONS PROCEDURES}

All operational procedures or revisions are reviewed and approved by RAC site management prior to implementation. In addition, all operational procedures are performance-based to ensure effective and appropriate instructions are being conveyed. As a minimum, all operational procedures are reviewed for adequacy and sufficiency on an annual basis.

\subsection{OPERATOR AID POSTINGS}

Principal application of operator aids is at control panels of conveyor systems. All operator aids posted are reviewed by RAC site management for acceptability, based upon equipment configuration and type of information that should be conveyed.

\subsection{EQUIPMENT AND PIPE LABELING}

All relevant components are labeled to communicate appropriate information. These components include control valves, general equipment, electrical panels and switch gear, instrumentation and gauges, and emergency equipment, including location of emergency eyewash stations and fire protection equipment.

All labels used for UMTRA Project site components, equipment, and/or systems meet the requirements of 29 CFR Parts 1910 and 1926, applicable NFPA codes, UMTRA Project design specifications, and the UMTRA Project Hazard

Communication Program regarding size, placement, and information to be conveyed.

\subsection{TAC FIELD OPERATIONS}

TAC is responsible for drilling of wells for ground water monitoring and limited soil sampling. This activity is conducted by subcontractors with TAC personnel providing oversight. The TAC Safety and Health Manager reviews and approves subcontractor health and safety plans prior to start of work. The TAC field technical representative is responsible for reviewing the subcontractor health and safety plan and overseeing the day-to-day drilling activities. The field technical representative has the authority to stop work, or not approve commencing, if the subcontractor health and safety plan is deficient or the subcontractor engages in unsafe work practices. Prior to each day's drilling activities, the field technical representative and a representative of the subcontractor perform a complete inspection and walkaround of the drilling equipment. The DOE and TAC health and safety staff also conduct independent oversight of drilling activities.

TAC personnel also perform surface water and ground water sampling at UMTRA Project sites. Surface water samples (approximately 1 liter in volume) are routinely collected upstream and downstream from sites. Ground water samples (approximately 1 liter in volume) are collected from monitoring wells located in the 
vicinity of sites. Water samples are preserved by adding small amounts ( $<5$ milliliters) of nitric or sulfuric acid. Trained TAC personnel, following approved procedures, perform water sampling using appropriate personal protective equipment, including face shields, gloves, chemical-resistant coveralls, and aprons. In addition, sampling chemicals are properly labeled and transported and stored in specially designed transportation containers to prevent inadvertent spillage or employee exposure.

UMTRA PROJECT DOCIMMENTATION: Relevant documentation includes RAC Construction Environment, Safety, and Health Management Plan; Industrial Hygiene Procedures Manual; Quality Assurance Program Plan; Vicinity Property Management Implementation Plan; Health Physics Procedures Manual; Total Quality Management Program; Training Procedures Manual; ORPS Program Manual; UMTRA Project Technical Assistance Contractor Environment, Safety, and Health Management Plan; Albuquerque Operations Manual; UMTRA Project Water Sampling Handbook; DOE UMTRA Project Office ORPS procedure; and subcontract special conditions. Based upon a review of these documents, the UMTRA Project Office has determined that the operations program developed for the UMTRA Project to control safety-related site activities is adequate. 


\subsection{QUALITY ASSURANCE}

The UMTRA Project has developed a quality assurance program based upon the quality assurance criteria prescribed in DOE Order $5700.6 \mathrm{C}$. This quality assurance program includes TAC and RAC quality assurance procedures to address site activities. For site activities, one of the principal areas of focus is the verification of techniques used by the subcontractors to construct the disposal cell and place tailings and cover material in accordance with the approved remedial action plan configuration.

Design control is included throughout the remediation of each UMTRA Project site, including site selection criteria, design specifications, final cell configuration, ground water well monitoring locations, etc. Potential revisions are reviewed for potential impact on any or all of these design elements prior to revisions being implemented.

The UMTRA Project Office conducts an active quality assurance oversight program to assure that remedial actions and associated activities are performed in a manner that will not jeopardize the success of the UMTRA Project or adversely impact the safety and health of workers or the public or the quality of the environment. In addition to oversight of site contractor operations, vendor surveillance is also performed on a predetermined basis, depending on the materials or services being supplied by the vendor.

All records of quality assurance activities are retained in accordance with the requirements prescribed by DOE Orders $5700.6 \mathrm{C}$ and $1324.2 \mathrm{~A}$.

UMTRA PROJECT DOCUMENTATION: Relevant documentation includes UMTRA Project, TAC, and RAC quality assurance program plans. The UMTRA Project Office has reviewed these plans and determined that the UMTRA Project quality assurance program is adequate. 


\subsection{EMERGENCY PREPAREDNESS}

All UMTRA Project sites have developed emergency action plans to address site-specific emergency preparedness issues, including logistics of local response teams. RAC APO procedures provide guidance for preparation of these plans to ensure consistency with the requirements of 29 CFR Parts 1910 and 1926, 40 CFR Part 112, and 49 CFR Part 172 Subpart $\mathbf{G}$. Site emergency action plans address the following topics:

- Subcontractor or other documents integrated or incorporated into the plan.

- Locations of plan for employee review.

- Identification of site emergency management organization members.

- Notification, record keeping, and reporting requirements.

- Description of responsibilities of site workers.

- Incident command and coordination protocols.

- Site communications systems.

- Site evacuation plan.

- Medical emergency response plan.

- Severe weather response plan.

- Fire/explosion response plan.

- Radiological/hazardous material release response plan.

- Emergency response training requirements.

The RAC APO reviews and approves site emergency response plans to ensure adequacy and sufficiency of the site programs.

Emergency response drills are held annually, prior to the site commencing work activities for the season. The emergency response drill includes representatives from the local emergency response organizations such as police and fire departments and emergency medical teams. This allows these local response organizations to familiarize themselves to the unique characteristics of UMTRA Project site programs, procedures, and accident scenarios.

Credible emergency response scenarios involving off-site personnel address vehicular accidents involving haul trucks transporting mill tailings on public highways or roads. Credible on site emergency response scenarios include truck fires, equipment accidents, and medical conditions. Site personnel are trained on responsibilities and duties for all site emergency response activities.

The TAC has developed site-specific emergency awareness/response plans for each site accessed by TAC personnel. TAC personnel are briefed on these plans prior to site visits.

UMTRA PROJECT DOCUMENTATION: Relevant documentation includes RAC Construction Environment, Safety, and Health Management Plan; UMTRA Project Technical Assistance Contractor Environment, Safety and Health Management Plan; site-specific health and safety plans; and emergency action plans. The UMTRA Project Office has reviewed these documents and determined that site emergency preparedness programs are adequate. 


\subsection{PROVISIONS FOR DECONTAMINATION}

Principal decontamination activities at UMTRA Project sites relate to radiological decontamination of equipment and materials and, occasionally, personnel. Decontamination of equipment is usually performed by the responsible subcontractor. Verification of decontamination of equipment is performed by site health physics personnel using instrumentation and survey techniques appropriate for the contamination of concern. Decontamination of personnel is performed using techniques consistent with industry standard methods and in accordance with RAC health physics procedures.

Administrative controls such as placarding, access control, exclusion zones and personal protective equipment use requirements are used to limit exposures to radiological contamination and the resulting need for decontamination. Radiological contamination controls are implemented through RAC APO and site-specific health physics procedures.

To ensure that no contaminated equipment, materials, or personnel are released from UMTRA Project sites, radiological verification surveys are performed by site health physics personnel using techniques applicable for the contaminant of concern. All equipment, materials, and personnel exiting designated areas of radiological contamination are subject to these surveys. Any equipment, material, or personnel that have radiological contamination exceeding applicable DOE guidelines are decontaminated. Additionally, transportation haul routes and offsite work areas bordering the control areas are routinely surveyed for radiological contamination, and any contaminated materials detected are promptly cleaned up.

Cases of personnel contamination, release of contaminated equipment and materials, and contamination of off-site areas are documented in the site health physics manager's daily log and also tracked on the ORPS system.

Because only limited quantities of hazardous materials are used on UMTRA Project sites, there is a remote possibility that hazardous material contamination could occur. In the event of such contamination, decontamination would follow site industrial hygiene procedures and recommended practices from material safety data sheets.

UMTRA PROJECT DOCUMENTATION: Relevant documentation includes RAC Radiation Protection Program; Health Physics Operations and Radiation Protection Procedures Manual; Health Physics Instrumentation Procedures Manual; Health Physics Administrative and Transportation Procedures Manual; Industrial Hygiene Procedures Manual. Based upon review of these documents, the UMTRA Project Office has determined that provisions for decontamination activities at UMTRA Project sites are adequate. 


\subsection{BIBLIOGRAPHY}

\section{NATIONAL CODES AND STANDARDS*}

10 CFR Part 835, Occupational Radiation Protection, U.S. Department of Energy.

29 CFR Part 1910, Occupational Safety and Health Standards, Occupational Safety and Health Administration.

29 CFR Part 1926, Safety and Health Regulations for Construction, Occupational Safety and Health Administration.

30 CFR Part 48, Training and Retraining of Miners, Mine Safety and Health Administration.

30 CFR Part 56, Safety and Health Standards - Surface Metal and Nonmetal Mines, Mine Safety and Health Administration.

40 CFR Part 112, Oil Pollution Prevention, U.S. Environmental Protection Agency.

40 CFR Part 192, Health and Environmental Protection Standards for Uranium and Thorium Mill Tailings, U.S. Environmental Protection Agency.

40 CFR Part 302, Designation, Reportable Quantities, and Notification, U.S. Environmental Protection Agency.

40 CFR Part 355, Emergency Planning and Notification, U.S. Environmental Protection Agency.

49 CFR Parts 100-180, Hazardous Materials Regulations, U.S. Department of Transportation.

49 CFR Parts 300-399, Motor Carrier Safety Regulations, U.S. Department of Transportation.

NFPA 10, Portable Fire Extinguishers, National Fire Codes, National Fire Protection Association.

NFPA 30, Flammable and Combustible Liquids Code, National Fire Codes, National Fire Protection Association.

\section{DOE ORDERS AND STANDARDS}

Order 1324.2A, Records Disposition, Change 1, April 9, 1992, U.S. Department of Energy, Washington, D.C.

Order 4330.4B, Maintenance Management Program, February 10, 1994, U.S. Department of Energy, Washington, D.C.

\footnotetext{
- Unless otherwise indicated, the most current versions of CFRs are applicable.
} 
Order 5000.3B, Occurrence Reporting and Processing of Operations Information, Change 1, January 19, 1993, U.S. Department of Energy, Washington, D.C.

Order 5400.5, Radiation Protection of the Public and the Environment, Change 2, January 7 , 1993, U.S. Department of Energy, Washington, D.C.

Order 5480.7A, Fire Protection, February 17, 1993, U.S. Department of Energy, Washington, D.C.

Order 5480.9A, Construction Project Safety and Health Management, April 13, 1994, U.S. Department of Energy, Washington, D.C.

Order 5480.11, Radiation Protection for Occupational Workers, Change 3, June 17, 1992 , U.S. Department of Energy, Washington, D.C.

Order 5480.19, Conduct of Operations Requirements for DOE Facilities, Change 1, May 18, 1992, U.S. Department of Energy, Washington, D.C.

Order 5480.20, Personnel Selection, Qualification, Training, and Staffing Requirements at DOE Reactor and Non-Reactor Nuclear Facilities, February 21, 1991, U.S. Department of Energy, Washington, D.C.

Order 5480.23, Nuclear Safety Analysis Reports, April 10, 1992, U.S. Department of Energy, Washington, D.C.

Order 5481.1B, Safety Analysis and Review System, Change 1, May 19, 1987, U.S. Department of Energy, Washington, D.C.

Order 5700.6C, Quality Assurance, August 21, 1991, U.S. Department of Energy, Washington, D.C.

DOE-STD-1027-92, Hazard Categorization and Accident Analysis Techniques for Compliance with DOE Order 5480.23, Nuclear Safety Analysis Reports, 1992, U.S. Department of Energy, Washington, D.C.

DOE-EM-STD-5502-94, Hazard Baseline Documentation, 1994, DOE Limited Standard, U.S. Department of Energy, Washington, D.C.

DOE/EH-0256T, Radiological Control Manual, April 1994, U.S. Department of Energy, Washington, D.C.

DOE Environment, Safety and Health Configuration Guide, Revision 0, July 30, 1993, U.S. Department of Energy, Washington, D.C. 


\section{UMTRA PROJECT OFFICE DOCUMENTS}

DOE (U.S. Department of Energy), 1995. UMTRA Project Environment, Safety, and Health Plan, DOE/AL/62350-181, DOE UMTRA Project Office, Albuquerque, NM (February 1995).

DOE (U.S. Department of Energy), 1993. Environment, Safety, and Health Regulatory Implementation Plan, DOE/AL/62350-44, DOE UMTRA Project Office, Albuquerque, NM (October 1993).

DOE (U.S. Department of Energy), 1994. UMTRA Project Waste Minimization and Pollution Prevention Awareness Program Plan, DOE/AL/62350-144, Rev. 0, DOE UMTRA Project Office, Albuquerque, NM (July 1994).

DOE (U.S. Department of Energy), 1994. UMTRA Project Office Quality Assurance Program Plan, DOE/AL/62350-76, Rev. 6, DOE UMTRA Project Office, Albuquerque, NM (September 1994).

DOE (U.S. Department of Energy), 1994. UMTRA Project Federal Occupational Safety and Health Program Plan, DOE/AL/62350-108, Rev. 1, DOE UMTRA Project Office, Albuquerque, NM (June 1994).

DOE (U.S. Department of Energy), 1988. Vicinity Property Management and Implementation Manual, UMTRA-DOE/AL-050601.0000, Rev. 1, DOE UMTRA Project Office, Albuquerque, NM (March 1988).

DOE (U.S. Department of Energy), 1990. UMTRA Project Site Management Manual, UMTRADOE/AL-400500, Rev. 1, DOE UMTRA Project Office, Albuquerque, NM (October 1990).

DOE (U.S. Department of Energy), 1994. Letter from F. Bosiljevac, DOE UMTRA, to D. Mathes, EM-451, of March 16, 1994.

\section{REMEDIAL ACTION CONTRACTOR DOCUMENTS}

RAC, 1994, Construction Environment, Safety, and Health Management Plan, MKF-UMTRA-4, Rev. 2, MK-Ferguson Company, Albuquerque, NM (November 1994).

RAC, 1995, Quality Assurance Program Plan, MKF-UMTRA-5, Rev. 10, MK-Ferguson Company, Albuquerque, NM (January 1995).

RAC, 1992, Waste Minimization and Pollution Prevention Program, MK-Ferguson Company, Albuquerque, NM (April 1992).

RAC, 1994, Industrial Hygiene Procedures Manual, MKF-UMTRA-29, Rev. 10, MK-Ferguson Company, Albuquerque, NM (April 1994). 
RAC, 1994, Occurrence Reporting and Processing System Program Manual, MKF-UMTRA-55, Rev. 1, MK-Ferguson Company, Albuquerque, NM (August 1994).

RAC, 1994, Transportation Requirements and Truck Inspection Plan, MKF-UMTRA-55, Rev. 0 , MK-Ferguson Company, Albuquerque, NM (April 1994).

RAC, 1994, Health Physics Procedures Manual, Rev. 39, MK-Ferguson Company, Albuquerque, NM (May 1994).

RAC, 1994, Health Physics Operations and Radiation Protection Procedures Manual, Rev. 25, MK-Ferguson Company, Albuquerque, NM (October 1994).

RAC, 1994, Health Physics Administrative and Transportation Procedures Manual, Rev. 22, MK-Ferguson Company, Albuquerque, NM (September 1994).

RAC, 1994, Health Physics Instrumentation Procedures Manual, Rev. 13, MK-Ferguson Company, Albuquerque, NM (October 1994).

RAC, 1994, Training Procedures Manual, MKF-UMTRA-58, Rev. 1, MK-Ferguson Company, Albuquerque, NM (October 1994).

RAC, 1994, Radiation Worker Training Course, Rev. 0, MK-Ferguson Company, Albuquerque, NM (January/May 1994).

RAC, 1994, Site Worker Course Book, MK-Ferguson Company, Albuquerque, NM (February 1994).

RAC, 1994, Project Procedures Manual, MKF-UMTRA-10, Rev. 20, MK-Ferguson Company, Albuquerque, NM (October 1994).

RAC, 1993, Total Quality Management Program, MKF-UMTRA-54, Rev. 1, MK-Ferguson Company, Albuquerque, NM (July 1993).

RAC, 1988, Vicinity Property Management Implementation Plan, MKF-UMTRA-7, Rev. 1, MKFerguson Company, Albuquerque, NM (December 1988).

\section{TECHNICAL ASSISTANCE CONTRACTOR DOCUMENTS}

TAC, 1986, UMTRA Project Technical Assistance Contractor Environment, Safety, and Health Management Plan, Revision 1, Jacobs Engineering Group, Inc., Albuquerque, NM.

TAC, 1994, UMTRA Technical Assistance Contractor Quality Assurance Program Plan, DOE/AL/62350-56, Rev. 5, Jacobs Engineering Group, Inc., Albuquerque, NM (October 1994).

TAC, 1994, Albuquerque Operations Manual, Jacobs Engineering Group, Inc., Albuquerque, NM. 
TAC, 1994, UMTRA Water Sampling Handbook, Jacobs Engineering Group, Inc., Albuquerque, NM (August 1994).

TAC, 1994, Environment, Safety, and Health Operating Envelope Database Desk Instruction Manual, Jacobs Engineering Group, Inc., Albuquerque, NM (July 1994).

\section{SITE-SPECIFIC DOCUMENTS}

DOE (U.S. Department of Energy), 1991. Remedial Action Plan and Site Conceptual Design for Stabilization of the Inactive Uranium Mill Tailings Site at Ambrosia Lake, New Mexico, UMTRA-DOE/AL-050516.0000, DOE UMTRA Project Office, Albuquerque, NM (November 1991 ).

DOE (U.S. Department of Energy), 1991. Remedial Action Plan and Site Design for Stabilization of the Inactive Uranium Mill Tailings Site at Grand Junction, Colorado, UMTRA-DOE/AL-050505.0000, DOE UMTRA Project Office, Albuquerque, NM (September 1991).

DOE (U.S. Department of Energy), 1992. Remedial Action Plan and Site Design for Stabilization of the Inactive Uranium Mill Tailings Site at Gunnison, Colorado, UMTRA-DOE/AL-050508.0000, DOE UMTRA Project Office, Albuquerque, NM (November 1992).

DOE (U.S. Department of Energy), 1993. Remedial Action Plan for the Codisposal and Stabilization of the Monument Valley and Mexican Hat Uranium Mill Tailings at Mexican Hat, Utah, UMTRA-DOE/AL-050509.0000, DOE UMTRA Project Office, Albuquerque, NM (February 1993).

DOE (U.S. Department of Energy), 1994. Remedial Action Plan and Site Design for Stabilization of the Inactive Uranium Processing Site at Naturita, Colorado, Working Draft, DOE/AL/62350-142, DOE UMTRA Project Office, Albuquerque, NM (September 1994).

DOE (U.S. Department of Energy), 1992. Remedial Action Plan and Site Design for Stabilization of the Inactive Uranium Mill Tailings Site at Rifle, Colorado, UMTRADOE/AL-050506.0000, DOE UMTRA Project Office, Albuquerque, NM (February 1992).

DOE (U.S. Department of Energy), 1987. Environmental Assessment of Remedial Action at the Ambrosia Lake Uranium Mill Tailings Site, Ambrosia Lake, New Mexico, DOE/EA0322, DOE UMTRA Project Office, Albuquerque, NM (June 1987).

DOE (U.S. Department of Energy), 1986. Final Environmental Impact Statement -Remedial Actions at the Former Climax Uranium Company Uranium Mill Site, Grand Junction, Mesa County, Colorado, DOE/EIS-126-F, DOE UMTRA Project Office, Albuquerque, NM (December 1986). 
DOE (U.S. Department of Energy), 1992. Environmental Assessment of Remedial Action at the Gunnison Uranium Mill Tailings Site Near Gunnison, Colorado, DOE/EA-0376, DOE UMTRA Project Office, Albuquerque, NM (February 1992).

DOE (U.S. Department of Energy), 1987. Environmental Assessment of Remedial Action at the Mexican Hat Uranium Mill Tailings Site, Mexican Hat, Utah, DOE/EA-0332, DOE UMTRA Project Office, Albuquerque, NM (October 1987).

DOE (U.S. Department of Energy), 1989. Environmental Assessment of Remedial Action at the Monument Valley Uranium Mill Tailings Site, Monument Valley, Arizona, DOE/EA0368, DOE UMTRA Project Office, Albuquerque, NM (June 1989).

DOE (U.S. Department of Energy), 1994. Environmental Assessment of Remedial Action at the Naturita Uranium Processing Site Near Naturita, Colorado, DOE/EA-0464, Rev. 5, DOE UMTRA Project Office, Albuquerque, NM (October 1994).

DOE (U.S. Department of Energy), 1990. Final Environmental Impact Statement - Remedial Actions at the Former Union Carbide Corporation Uranium Mill Sites, Rifle, Garfield County, Colorado, DOE/EIS-132-F, DOE UMTRA Project Office, Albuquerque, NM (March 1990).

RAC, 1994, Ambrosia Lake ES\&H Plans Book, Rev. 3, MK-Ferguson Company, Ambrosia Lake, NM (June 1993).

RAC, 1994, Grand Junction ES\&H Plans Book, Rev. 1, MK-Ferguson Company, Grand Junction, CO (September 1994).

RAC, 1994, Gunnison ES\&H Plans Book, Rev. 1, MK-Ferguson Company, Gunnison, CO (March 1994).

RAC, 1994, Mexican Hat/Monument Valley ES\&H Plans Book, Rev. 1, MK-Ferguson Company, Mexican Hat, UT (July 1994).

RAC, 1994, Naturita ES\&H Plans Book, Rev. 2, MK-Ferguson Company, Naturita, CO (September 1994).

RAC, 1994, Rifle ES\&H Plans Book, Rev. 2, MK-Ferguson Company, Rifle, CO (May 1994).

Site subcontractor procedures and work plans as required by subcontract, RAC direction, or subcontractor management.

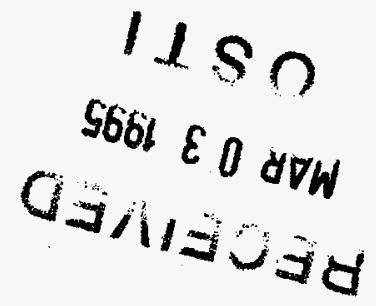

